\title{
ELEMENTY POJEDNANIA W LITURGII EUCHARYSTYCZNEJ I MISTAGOGIA MODLITW EUCHARYSTYCZNYCH O TAJEMNICY POJEDNANIA ${ }^{1}$
}

\section{ELEMENTS OF RECONCILIATION IN THE EUCHARISTIC LITURGY AND THE MISTAGOGY OF EUCHARISTIC PRAYERS FOR MASSES OF RECONCILIATION}

This article discusses the elements of reconciliation present in the Eucharistic celebration, focusing in particular on deepening the mistagogical sense of the liturgical rite and the words of Eucharistic prayers for masses of reconciliation (EPR). Broadened horizons of our knowledge will help us to ultimately reach the depths of the richness of the mystery experienced in the Eucharistic celebration.

We realize how ubiquitous the theme of reconciliation is in the Eucharistic liturgy by presenting the various forms of the penitential act, the apologies of the priest as well as the communion rites redolent of reconciliation. All of these seem to be crowned by the discussion of the theme of reconciliation present in the newest typical edition of the Roman missal (2002).

The theme of reconciliation is present in a special way in the Eucharistic prayers for masses of reconciliation.

The first EPR emphasizes man's call to holiness and presents the teandric dimension of reconciliation as a renewal of the Covenant and a means of rediscovering anew the way to the Father's home.

${ }^{1}$ Artykuł jest częścią rozprawy doktorskiej: Les prières eucharistiques pour la réconciliation. Teologie et mystagogie pour aujourd'hui (Modlitwy eucharystyczne o tajemnicy pojednania. Teologia i mistagogia na dzisiaj), napisanej pod kierunkiem Prof. Paul De Clerck i Prof. Kristiaan Depoortere i obronionej w Instytucie Katolickim w Paryżu w 2005 r.; tekst w cudzysłowach jest tłumaczeniem oryginalnego tekstu MEP z języków francuskiego (I MEP) lub niemieckiego (II MEP), tekst pisany kursywą jest zaczerpnięty z polskiego tłumaczenia MEP; skróty w nawiasach zwykłych odpowiadają poszczególnym częściom modlitwy eucharystycznej: Pref - Prefacja; PSc - Post - Sanctus; Ep - Epikleza konsekracyjna; Rec - Recytatyw ustanowienia; A - Anamneza; Epk - Epikleza Komunijna; Mw - Modlitwy wstawiennicze. 
The second EPR shows reconciliation in the horizontal dimension, where God the Father in his work of salvation stretches out His both hands - the Son and the Holy Spirit - in order to transfigure the divided and torn humanity and lead it to perfect communion.

The Eucharist is the fullest sacramental realization of Christ's salvation. In the context of the Eucharist celebrated with one of the two EPR, we are able to gain a better understanding of the fact that the contemporary Church feels responsible for the grand work of reconciliation with God, the neighbor, and the entire world. EPR is a very concrete answer to the needs of the Church at the threshold of the third millennium.

„aby Kościół jaśniał pośród ludzi, jako znak jedności i narzędzie pokoju"

(II MEP Mw)

Wśród wielkich dobrodziejstw, jakie człowiek otrzymał od Boga w historii zbawienia, miejsce uprzywilejowane należy się sakramentom, a w sposób szczególny Eucharystii. Eucharystia jest najbardziej pełną realizacją sakramentalną Chrystusowego zbawienia. $\mathrm{Na}$ zaproszenie Pana, podczas Eucharystii chrześcijanie gromadzą się, by tworzyć lud Boży. Podczas jej celebracji słuchają słowa Bożego, proklamowanego w imię Jezusa oraz celebrują we wspólnocie Kościoła pamiątkę śmierci i zmartwychwstania Chrystusa. W oczekiwaniu na spotkanie ostateczne w chwale niebios już teraz przez Komunię świętą biorą udział w uczcie Baranka (Ap 19, 9) ${ }^{2}$.

W kontekście Eucharystii celebrowanej $\mathrm{z}$ jedną $\mathrm{z}$ dwóch modlitw eucharystycznych o tajemnicy pojednania (MEP), możemy lepiej zrozumieć, że Kościół współczesny czuje się naprawdę odpowiedzialny za wielkie dzieło pojednania $\mathrm{z}$ Bogiem, braćmi i całym światem. Rozważane $\mathrm{w}$ całości MEP, nieustannie proponują wspólnocie chrześcijańskiej solidny motyw dziękczynienia Bogu Ojcu jako dowód wdzięczności za uniwersalne dzieło pojednania. Pascha Chrystusa aktualizuje się każdorazowo w Kościele poprzez przezwyciężanie niezgody i podziałów, jednocześnie otwiera na nowość życia w Duchu i na zaangażowanie się dla dobra braci, tak aby czas Kościoła stawał się nieustannie czasem pojednania i pokoju (II MEP Mw) ${ }^{3}$.

${ }^{2}$ P. De Clerck, Le salut, ou la réconciliation et ses réalisations sacramentelles, „La Maison Dieu” (dalej skrót: LMD) 172 (1987), s. 37-38.

${ }^{3}$ A. Catella, G. Cavagnoli, Le preghiere eucaristiche. Analisi dei contenuti e indicazioni catechistiche, Milano, 1989, s. 111. 
Kościół, umożliwiając wiernym udział w mądrości Boskiego planu zbawienia, angażuje się bardzo konkretnie w stworzenie odpowiednich warunków, aby wszyscy uczestnicy liturgii mogli bardziej konkretnie poznać miłosiernego Boga i szczodrze odpowiedzieć na Jego propozycje zbawienia. Inaczej mówiąc, Kościół, któremu została powierzona tajemnica Eucharystii, odczuwa wdzięczność, ale jednocześnie jest zobowiązany do całkowitego złączenia się z Boskim dziełem pojednania. Podejmując między innymi odpowiedzialność za realizację pojednania, Kościół przedstawia swoje dziękczynienie za pomocą MEP podczas celebracji liturgii eucharystycznej ${ }^{4}$.

\section{Elementy pojednania obecne w celebracji eucharystycznej}

Starodawna tradycja liturgiczna, wspólna dla Wschodu i Zachodu, wyraża wiarę Kościoła w charakter oczyszczający i leczniczy Eucharystii. Charakter ten, obecny w Sakramentarzach, podobnie jak w modlitwach liturgicznych używanych dzisiaj, komunikuje istotę, według której Eucharystia odpuszcza grzechy tym wiernym, którzy $\mathrm{z}$ odpowiednim usposobieniem $\mathrm{w}$ niej uczestniczą. To przeświadczenie wypływa $\mathrm{z}$ opisu biblijnego Ostatniej Wieczerzy, przekazanego nam przez tradycję, który brzmi: „Krew Przymierza, która za wielu będzie wylana na odpuszczenie grzechów" (Mt 26, 28). Ten dodatek św. Mateusza do tradycji synoptycznej służy wyjaśnieniu sensu, jaki ewangelista nadaje śmierci Jezusowej ${ }^{5}$. Kościół rozpoznał ten akcent efektu odkupieńczego kielicha eucharystycznego i wprowadził te słowa, obecne wcześniej w Kanonie rzymskim, do słów konsekracyjnych wszystkich modlitw eucharystycznych, które pojawiły się w Kościele po reformie Pawła VI: „To jest bowiem kielich Krwi mojej nowego i wiecznego przymierza, która za was i za wielu będzie wylana na odpuszczenie grzechów”. Tekst I MEP podkreśla ten akcent odkupieńczy, wprowadzając również identyczną treść do słów ustanowienia, które poprzedzają formułę konsekracji kielicha: „Wiedząc, że pojedna wszystko w sobie przez krew wylaną na krzyżu, wziął kielich $\mathrm{z}$ winem".

$\mathrm{W}$ poniższej analizie, nie zagłębiamy się $\mathrm{w}$ detale rozwoju historycznego relacji teologicznych i doktrynalnych pomiędzy sakramentami Eucharystii i pokuty. Zadawalające wydaje się być stwierdzenie, iż - według dotychczasowych opracowań - Eucharystia odpuszcza wszystkie grzechy, nawet śmiertelne. Nie-

${ }^{4}$ J. Decyk, Modlitwy eucharystyczne o tajemnicy pojednania, „Studia Theologica Varsaviensia” 36 (1998), nr 1, s. 134-135.

${ }^{5}$ B. de Boissieu, Eucharistie et pénitence, w: Eucharistia. Encyclopédie de l'Eucharistie, M. Brouard (red.), Paris 2002, s. 573; por. J. M. Tillard, Le pain et la coupe de la réconciliation, „Concilium” 61 (1971), s. $35-48$. 
mniej jednak pewna część grzechów ciężkich wymyka się tej mocy przebaczającej. Teologowie w ciągu wieków podkreślali ten charakter ekspiacyjny i oczyszczający Eucharystii, który leczy i przebacza grzechy. Ponadto, Msza święta aktualizuje i uobecnia misterium krzyża Chrystusowego, przez który wszystkie grzechy zostały odkupione. W rzeczywistości, to podczas Eucharystii Chrystus odnawia swoje przymierze, które uwalnia nas z grzechów ${ }^{6}$.

Naszym zamiarem nie jest tym bardziej wyjaśnianie sposobu tego przebaczania. Ograniczamy się do stwierdzenia, że przebaczenie grzechów przez sakrament Eucharystii jest wzmiankowane. W niektóry liturgiach Kościołów wschodnich istnieją akty pokutne wcielone $\mathrm{w}$ modlitwę eucharystyczną ${ }^{7}$. Natomiast w liturgiach Zachodu przebaczenie dokonuje się przez ofiarę albo przez sakrament, czy też przez oboje razem wzięte ${ }^{8}$.

Inna tradycja towarzyszy tej pierwszej, a mianowicie odpowiednie przygotowanie jest niezbędne, ażeby można było skorzystać z eucharystycznego charakteru przebaczenia. Liturgia nie precyzuje, na czym polega to przygotowanie. Według niektórych teologów koniecznością jest stan łaski uświęcającej. Inni uważają, iż wystarczający jest żal za grzechy i uznanie siebie za człowieka grzesznego. W każdym bądź razie, chodzi o sytuację, w której chrześcijanin nie znajduje się w jawnym odstępstwie ani od Boga, ani Kościoła. Niektórzy z kolei zadowalają się tylko dobrą intencją pojednania sakramentalnego w czasie późniejszym i przyzwalają na Komunię świętą uprzednią; jest to przypadek związany z obrzędem pojednania wielu penitentów $\mathbf{z}$ ogólną spowiedzią i rozgrzeszeniem. Jeszcze innym wystarcza trwanie w komunii wiary z Kościołem, na manierę protestancką. Są również tacy, którzy uważają, że można przystępować do Komunii świętej z konieczności, bez możliwości uprzedniego pojednania sakramentalnego. Można się tylko zapytać, czy istnieje taki rodzaj konieczności?

${ }^{6}$ Jan Paweł II, Encyklika Ecclesia de Eucharistia, 36-37; C. Blanchette, Pénitence et Eucharistie. Dossier d'une question controversée, Montréal - Paris 1989, s. 135-158; J. M. Tillard, Pénitence et Eucharistie, LMD 90 (1967), s. 103-131.

${ }^{7}$ L. Ligier, Pénitence et Eucharistie en Orient. Théologie sur une interférence de prière et de rite, „Orientalia Christiana Periodica”, 29 (1963), s. 5-48; tenże, Dimension personnelle et dimension communautaire de la pénitence en Orient, LMD 90 (1967), s. 172-175; Ch. Renoux, Eucharistie et rémission des péchés dans les Anaphores arméniennes, „Didaskalia” 3 (1973), s. 201-214.

${ }^{8}$ C. Blanchette, Pénitence et Eucharistie, art. cyt., s. 148-151; I. Sottocornola, Suggerimenti per la catechesi e la pastorale della nuova liturgia penitenziale, „Ephemerides Liturgicae” 89 (1975), s. 256-258; Commission Théologique Internationale, La réconciliation et la pénitence, „La documentation catholique" (dalej skrót: DC) 80 (1983), s. 1168-1169.

9 M. Clavier, Eucharistie: la 'préparation pénitentielle' est-elle bien nécessaire?, „Questions Liturgiques" 85 (2004), s. 138-140; D. Moreau, Prières eucharistiques pour la réconciliation: observation et notes analytiques, „Bulletin National de Liturgie” 14 (1980), s. 78; por. B. Marliangeas, Réconciliation aujourd'hui. Perspectives théologiques et pastorales, Paris 1989, s. 43-47. 
Znajdujemy się więc wobec podwójnej tradycji, czy też - prawdę mówiąc - podwójnej teologii. Eucharystia odpuszcza wszystkie grzechy, czy też wymaga ona odpowiedniego przygotowania, oczyszczenia uprzedniego, które zawierałoby uwolnienie od grzechu. $\mathrm{Z}$ tego podwójnego przeświadczenia, które odnajdujemy w ciągu wieków, pierwsza opcja jest obecna i bardziej zamanifestowana w modlitwie liturgicznej, podczas gdy druga, której nie można nie zauważyć, przede wszystkim wypływa $\mathrm{z}$ teologii. Pozostawiamy jednak teologom troskę o wyjaśnienie zawiłości wzajemnego odniesienia sakramentów Eucharystii i pokuty, i przechodzimy do elementów celebracji eucharystycznej, które posiadają wydźwięk pojednania.

\subsection{Akt pokuty}

Wśród obrzędów wstępnych Mszy świętej ogólne wprowadzenie do mszału rzymskiego wylicza między innymi akt pokuty. Stwierdza ono: „Kapłan wzywa do aktu pokuty, jaki po krótkiej chwili milczenia spełnia cała społeczność w formie wspólnego wyznania, kapłan zaś kończy je absolucją, która jednak nie posiada skuteczności sakramentu pokuty" (OWMR 51). Nie wchodzimy tutaj w dyskusję nad charakterem sakramentalnym, czy też nie-sakramentalnym aktu pokutnego ${ }^{10}$, czy też nad miejscem najbardziej odpowiednim dla aktu pokutnego $\mathrm{w}$ ramach celebracji eucharystycznej ${ }^{11}$. Zadawalamy się zasygnalizowaniem faktu, iż akt pokutny nie jest rytem sam $\mathrm{w}$ siebie, ale wpisuje się wraz $\mathrm{z}$ innymi elementami w obrzędy wstępne. To wraz z nimi, wraz z ich specyficzną dynamiką, należy rozumieć i razem umieścić akt pokutny. Przywołajmy raz jeszcze OWMR, które w następujących słowach opisuje rolę obrzędów wstępnych całej liturgii: „Ich celem jest to, aby wierni gromadzący się razem, stanowili wspólnotę oraz przygotowali się do uważnego słuchania Bożego słowa i godnego sprawowania Eucharystii” (OWMR 46).

Wprowadzony przez ojców reformy do Mszału rzymskiego, akt pokutny nie był przyjęty $\mathrm{z}$ wielkim entuzjazmem. Obiekcje podnoszone wobec niego

${ }^{10}$ A. Nocent, L'acte pénitentiel du nouvel Ordo Missae: Sacrement ou sacramental?, „Nouvelle Revue Théologique" 91 (1969), s. 965-976; P. De Clerck, La réconciliation dans l’Assemblée eucharistique. La valeur de la 'préparation pénitentielle', „Prétres diocésains” 1995, s. 119-130; B. Marliangeas, L'éventail actuel des formes de célébration, w: Pénitence et réconciliation aujourd'hui, CNPL (Centre national de pastorale liturgique), Lyon 1974, s. 108; Du bon usage de la liturgie, CNPL, Paris 1999, s. 38.

${ }^{11}$ H. Hollerweger, Ritus der Versöhnung mit Gott und den Brüdern: Schuldbekenntnis und Friedensgruß als Einheit, w: Bewahren und Erneuern: Studien zur Messliturgie, R. Meßner, E. Nagel, R. Pacik (red.), Innsbruck - Wien 1995, s. 274-284; B. Kranemann, Die Versöhnung mit Gott und den Menschen in der Feier der Gemeindemesse: Zum Ort des Bußaktes im Ordo Missae, „Heiliger Dienst” 51 (1997), s. 101-107. 
dotyczyły dynamiki celebracji liturgicznej. Akt pokutny znajduje się jakby trochę wciśnięty pomiędzy dwoma śpiewami: pieśnią na rozpoczęcie liturgii, która zazwyczaj jest radosną i pociągającą oraz śpiewem Kyrie eleison - Gloria.

Ponadto, trzecia forma aktu pokutnego, poprzez użycie Kyrie eleison, tropowanego jako śpiewu $\mathrm{w}$ ramach aktu pokutnego, faworyzuje przemianę inwokacji uwielbiających Chrystusa $\mathrm{w}$ „samooskarżanie i w prośby przedstawiające nędzę ludzkości". Używanie tej formy aktu pokutnego może sprawić, że bardzo łatwo pomylimy akt pokuty ze śpiewem Kyrie eleison, które powinno nastąpić dopiero po akcie pokuty (OWMR 51/52). W rzeczywistości, Kyrie eleison jest śpiewem inwokacyjnym, poprzez który wierni uwielbiają Chrystusa i wypraszają Jego miłosierdzia. Naturalnie występuje on po akcie pokutnym i nie powinien zajmować miejsca tego ostatniego. Zresztą, cały czas trwają dyskusje na temat miejsca najbardziej odpowiedniego dla aktu pokutnego w ramach liturgii eucharystycznej ${ }^{12}$.

W każdym bądź razie, dla wszystkich akt pokutny jest uciekaniem się do miłosierdzia Bożego. Kapłan przez swoje wezwanie przypomina nam prawdziwy sens tego przygotowania. Wprowadza nas poprzez następujące słowa: „Uznajmy przed Bogiem, że jesteśmy grzeszni, abyśmy mogli z czystym sercem złożyć Najświętszą Ofiarę". To uznanie stanu naszej grzeszności, to znaczy naszej potrzeby miłosierdzia Bożego, nie powinno być prawdziwym wyznaniem naszych grzechów. Grzech jest zawsze jakąś ucieczką od Boga, mniej lub bardziej ciężki, bardziej lub mniej bezpośredni, jako taki; czyni nas niezdolnymi do celebracji Przymierza, jakim jest liturgia. Abyśmy mogli owocnie skorzystać $\mathrm{z}$ ofiary eucharystycznej, która nas zbawia, konieczne jest, abyśmy uprzednio rozpoznali $\mathrm{w}$ sobie taką potrzebę i odpowiednio się do tego przygotowali. Zgromadzenie liturgiczne pozostaje przez chwilę w ciszy, aby uświadomić sobie swój stan grzeszności i potrzebę oczyszczenia w świetle, które w tej chwili płynie od Boga.

Mszat rzymski proponuje nam wybór jednego z trzech - a nawet czterech form aktu pokuty. Wybór powinien być oczywiście zależny od rodzaju celebracji i czasu liturgicznego.

${ }_{12}$ Do prześledzenia rozwoju historycznego aktu pokuty i prac związanych z Mszałem rzymskim można skonsultować: B. Botte, Le mouvement liturgique. Témoignages et souvenirs, Paris 1973, s. 180; P. De Clerck, L'»Ordo Missae" de Vatican II: ses innovations et sa réception, w: L'Eucharistie: célébrations, rites, piétés, A. M. Triacca, A. Pistoia (red.), Roma 1995, s. 186-187. 


\subsubsection{Con fiteor - „Spowiadam się”}

Pierwszą formę aktu pokutnego stanowi Confiteor ${ }^{13}$, czyli Spowiadam sie $B o g u$, który jest recytowany wspólnie przez całe zgromadzenie liturgiczne. Zarówno celebrans główny, jak i wierni uznają się za grzesznych wobec Boga oraz wobec siebie nawzajem, powołując na świadków Najświętszą Maryję Pannę, aniołów i świętych. W precyzji określeń grzechu „myślą, mową, uczynkiem i zaniedbaniem" dostrzegamy pewną gradację, która obejmuje winy na polu czysto wewnętrznym, jak również te, które mogą być postrzegane naszymi zmysłami. Jest również bardzo znaczące, iż w Confiteor modlimy się o wstawiennictwo współbraci w naszej intencji.

Celebrans kończy ten akt pokutny poprzez formułę rozgrzeszenia: „Niech się zmiłuje nad nami Bóg wszechmogący i odpuściwszy nam grzechy doprowadzi nas do życia wiecznego". Jak zostało to podkreślone powyżej, w cytowanych słowach OWMR, forma rozgrzeszenia aktu pokutnego nie jest absolucją sakramentalną. Można ją rozpatrywać w randze sakramentalium (ex opere orerantis Ecclesiae), to znaczy, że przygotowuje ona - ze skutecznością proporcjonalną do naszej dyspozycji - celebrację eucharystyczną, sakrament, który aktualizuje ofiarę krzyża Chrystusowego ${ }^{14}$.

\subsubsection{Druga forma aktu pokutnego}

Drugą formę wyznania win stanowią „wersety dialogowane”. Jest to wyznanie bardzo proste, $z$ pierwszym wersetem wypowiadanym przez celebransa głównego, po którym następuje odpowiedź zgromadzenia liturgicznego:

K.: Zmiłuj się nad nami, Panie. W.: Bo zgrzeszyliśmy przeciw Tobie.

K.: Okaż nam, Panie, miłosierdzie swoje. W.: I daj nam swoje zbawienie.

Forma ta pojawia się po raz pierwszy w dodatku do Schematu 281 de Missa podkomisji przygotowującej odnowę soborową ${ }^{15}$.

Liturgia często ucieka się do krótkich zapożyczeń biblijnych, aby w ten sposób wyrazić modlitwę zgromadzenia. W takich wypadkach celebrans lub ktoś odpowiednio przygotowany wypowiada „werset” domagający się „odpowiedzi” ze strony zgromadzenia. W naszej formule pierwszy werset wraz ze swoją odpowiedzią tworzy wątek biblijny wołania o miłosierdzie Boże, po

${ }^{13}$ Do prześledzenia rozwoju historycznego zob. J. A. Jungmann, Missarum Sollemnia. Explication génétique de la Messe romaine, t. 2, Paris 1952, s. 47-62; A. G. Martimort, L'Église en Prière. Introduction à la Liturgie, t. 2, Paris 1983, s. 167-168; A. Nocent, L'acte pénitentiel du nouvel Ordo Missae, art. cyt., s. 957-959.

${ }^{14}$ R. Le Gall, La messe au fil de ses rites, Chambray-lès-Tours 2001, s. 29-30.

${ }^{15}$ P. De Clerck, L’»Ordo Missae« de Vatican II: ses innovations et sa réception, art.cyt., s. 186. 
którym następuje wyznanie grzechów [por. Jer 14, 20]. Druga para wersetów jest zapożyczeniem z psalmu 85[84], 8.

Dialog pokutny kończy formuła rozgrzeszenia, wypowiadana przez kapłana, identyczna $\mathrm{z}$ tą, która jest stosowana po pierwszej formie aktu pokutnego.

Po tych dwóch formach aktu pokutnego, zakończonych słowami absolucji, następuje śpiew lub recytacja Kyrie eleison: Jezus jest Panem. Korzenie tej aklamacji greckiej możemy odnaleźć w liturgii wschodniej już w IV w. Służyła ona jako odpowiedź zgromadzenia na usłyszane intencje modlitwy wiernych, odczytywane przez diakona. Na Zachodzie św. Grzegorz Wielki (+604) opisuje, iż Kyrie za jego czasów jest śpiewane w Rzymie na początku liturgii mszalnej przez duchowieństwo lub chór, a następnie powtarzane przez wiernych. To za jego czasów dołączono do wezwania Kyrie inwokację paralelną: Christe eleison ${ }^{16}$.

Początkowo wszystkie trzy wezwania: Kyrie, Christe, Kyrie były skierowane do Chrystusa. To dopiero $\mathrm{w}$ kolejnych wiekach ich używania przypisano poszczególnym inwokacjom orientację trynitarną: pierwsze Kyrie miało być zaadresowane do Boga Ojca, Christe naturalnie do Chrystusa, natomiast ostatnie Kyrie do Ducha Świętego. Reforma liturgiczna przywróciła całemu Kyrie jej wymiar chrystologiczny, ale trudno powiedzieć, w jakim stopniu zostało to już przyjęte i zaakceptowane.

Tłumaczenie Panie, zmiłuj się nad nami powinno być rozumiane w sensie uwielbienia skierowanego do Chrystusa. Nowe błaganie z prośbą o przebaczenie grzechów nie miałoby bowiem sensu po słowach rozgrzeszenia uprzednio wypowiedzianych przez kapłana ${ }^{17}$.

Powyższe rozumienie jest natychmiast potwierdzone przez samą liturgię w radosnym hymnie Chwała na wysokości Bogu. Hymn ten, początkowo grecki, wchodzi do liturgii łacińskiej w IV lub V w. Przez niego „Kościół zgromadzony w Duchu Świętym uwielbia oraz błaga Boga Ojca i Baranka” (OWMR 53).

„Panie Boże, Baranku Boży, Synu Ojca.

Który gładzisz grzechy świata, zmiłuj się nad nami.

Który gładzisz grzechy świata, przyjm błaganie nasze.

Który siedzisz po prawicy Ojca, zmiłuj się nad nami”18.

${ }^{16}$ J. A. Jungmann, Missarum Sollemnia, dz. cyt., t. 2, s. 87-103; L. Deiss, La messe. Sa célébration expliquée, Paris 1989, s. 26-30.

${ }^{17}$ A. Join-Lambert, Guide pour comprendre la messe, Paris 2003, s. 67.

${ }^{18}$ Mszał Rzymski dla diecezji polskich, Poznań 1986, s. 11*; Lucien Deiss postrzega przeciwnie ten akt uwielbienia, nazywając go „nowym obłokiem pokutnym na niebie uwielbienia”, La messe. Sa célébration expliquée, dz. cyt., s. 27; niemniej jednak, należy podkreślić, iż rzeczywistość ta ukazuje dobrze bo- 


\subsubsection{Trzecia forma aktu pokutnego}

Trzecia forma aktu pokutnego to rozwinięcie chrystologiczne Kyrie. Można powiedzieć, że to do tej formy jesteśmy najbardziej przyzwyczajeni w naszych celebracjach liturgicznych (Francja, Niemcy). Daje ona różne możliwości wyboru, zaproponowane przez $M s z a 1^{19}$, czy też zespół przygotowujący liturgię. Ta potrójna prośba o przebaczenie grzechów, skierowana ku Chrystusowi, ma formę litanijną i jest połączona z Kyrie lub podobnym tekstem. W każdym bądź razie, po zakończeniu wezwań następuje forma rozgrzeszenia, znana z dwóch poprzednich schematów, ale nie ma śpiewu lub recytacji Kyrie. Czuwać natomiast należy, aby wezwania nie zostały przekształcone w rachunek sumienia, gdyż winne być one skierowane do Chrystusa, który nas zbawia ${ }^{20}$.

Naszą uwagę przykuwają wezwania proponowane jako drugie przez francuski Missel romain w tej trzeciej formie aktu pokutnego (Mszał polski podaje tę formułę, lekko zmienioną, jako szóstą, s. $9^{*}$ ). Odnajdujemy tu bowiem formę aktu pokutnego, zaproponowanego po raz pierwszy we francuskim schemacie Mszy świętej na rok święty 1974-1975:

K. Panie Jezu, który przyszedłeś na świat, aby pojednać nas z Bogiem Ojcem, zmiłuj się nad nami.

W. Zmiłuj się nad nami.

K. Chryste, który przyjąłeś na siebie nasze grzechy, abyśmy się stali uczestnikami świętości Bożej, zmiłuj się nad nami.

W. Zmiłuj się nad nami.

K. Panie, Synu Boży, który żyjesz z Ojcem w jedności Ducha Świętego, aby się wstawiać za swoim ludem, zmiłuj się nad nami.

W. Zmiłuj się nad nami.

gactwo liturgii eucharystycznej, przenikniętej w każdym wymiarze elementami pojednania. Ukazuje dobitnie, że nie można zawężać wymiaru pojednania jedynie do aktu pokutnego czy też MEP.

${ }^{19}$ Missel Romain, Paris 1977, s. 396-397 i 1020-1021; Mszał rzymski dla diecez ji polskich, wymienia 11 rodzajów wezwań w trzeciej formie aktu pokutnego, dz. cyt., s. $6^{*}-10^{*}$.

${ }^{20}$ M. Clavier, Eucharistie: la 'préparation pénitentielle' est-elle bien nécessaire?, art. cyt., s. 143; por. D. Dufrasne, La „préparation pénitentielle” dans le 'Nouveau Missel des dimanches' (1970-1980), „Communautés et Liturgies" 62 (1980), s. 296-319. 
Podobnie jak w przypadku I MEP, której pierwszy schemat był proponowany razem $\mathrm{z}$ tym aktem pokutnym, tekst naszych wezwań przepełniony jest reminiscencjami biblijnymi. Najprawdopodobniej autorem tego tekstu jest również Didier Rimaud, gdyż notatki ręcznie uczynione, na marginesie maszynopisu, przypominają jego charakter pisma. Podaje on następujące referencje biblijne do tekstu wezwań aktu pokutnego:

- pierwsze wezwanie aktu (Rz 5, 10; 2 Kor 5, 18; J 10, 25-30);

- drugie wezwanie aktu (Iz 52, 13; Dz 3, 13.26; 4, 27.30; 2 Kor 5, 21; Ga 3, 13);

- trzecie wezwanie aktu ( $\operatorname{Hbr} 9,24 ; \operatorname{Rz} 5,2 ; 8,34 ;$ Ef 2, $18 ; 1 \mathrm{~J} \mathrm{2,} 1)^{21}$.

$\mathrm{Na}$ podstawie przytoczonych fragmentów Pisma świętego widzimy, że wezwania te nie posiadają wymiaru trynitarnego, lecz chrystologiczny.

\subsubsection{Poświęcenie wody $i$ aspersja wiernych}

W niedzielę, zamiast aktu pokutnego, Mszał rzymski daje możliwość dokonania poświęcenia wody i pokropienia nią wiernych ze śpiewem odpowiedniej antyfony. Forma ta, posiadająca charakter wybitnie chrzcielny, jest zbyt często zapominana. Jest ona specjalnie przeznaczona na pewne okresy liturgiczne, jak czas paschalny, ale bynajmniej nie jest ona na ten czas jedynie zastrzeżona, jak wyraża to Ogólne wprowadzenie do Mszału rzymskiego: „W dniu Pańskim, zwłaszcza w Okresie Wielkanocnym, zamiast zwykłego aktu pokuty może się odbyć błogosławieństwo wody i pokropienie nią wiernych na pamiątkę chrztu" (OWMR 51) 22 .

W czasie paschalnym używa się wody poświęconej podczas Wigilii Paschalnej. W innym wypadku, kapłan błogosławi wodę i następnie kropi nią wiernych. Podczas Mszy św. w małych grupach, można zaproponować procesjonalne podejście całego zgromadzenia liturgicznego do kociołka czy wazy, gdzie każdy indywidualne uczyni znak krzyża wodą święconą. W każdym bądź razie, ryty te winne być wykonane z prostotą i godnością, tak aby każdy uczestnik liturgii mógł uświadomić sobie wielki dar chrztu świętego, który stał się jego udziałem. Możliwość użycia aspersji zdaje się równoważyć charakter bardziej pokutny trzech pierwszych form aktu pokutnego. Czwarta forma aktu pokutnego wydaje się bardziej słusznie usytuować rozpoczęcie celebracji

${ }^{21}$ Kongregacja Kultu Bożego, Textus gallicus Missae et precis eucharisticae pro Anno Sanclo, Archives CNPL, Dossier PE-2. Mszał rzymski, dz. cyt., s. 9*.

${ }^{22}$ Sacramentary w Stanach Zjednoczonych przewiduje „Obrzęd poświęcenia wody i pokropienia wiernych" na pierwszym miejscu przed wszystkimi innymi możliwościami aktu pokutnego; por. P. De Clerck, L’»Ordo Missae« de Vatican II: ses innovations et sa réception, art. cyt., s. 187. 
eucharystycznej na gruncie chrzcielnym, który jest istotą naszej przynależności do wspólnoty Kościoła ${ }^{23}$.

Charakter oczyszczający jest oczywiście dobrze wyrażony przez modlitwę kończącą obrzęd poświęcenia wody i pokropienia wiernych:

„Niech Bóg wszechmogący oczyści nas zgrzechówi sprawi, abyśmy przez odprawienie tej eucharystycznej Ofiary stali się godnymi udziału w uczcie niebieskiej"24.

\subsection{Obrzędy Komunii świętej}

Komunia święta wiernych ukazuje się nam jako uwieńczenie całej celebracji eucharystycznej. Ofiara eucharystyczna, aktualizująca sakramentalnie ofiarę krzyżową Chrystusa, czyni nas uczestnikami jedności Ojca i Syna, i Ducha Świętego, czyli pozwala nam stać się uczestnikami komunii trzech osób Boskich (1 J 1, 3-4).

Ofiara nie może być spełniona bez uczty sakralnej, została ona ustanowiona, by nas doprowadzić do pełnej komunii z Bogiem. Bez Komunii, ofiara bowiem traci swój cel, tak jak sam Jezus to zaznaczył, ustanawiając sakrament Eucharystii: „Bierzcie i jedzcie, (...) Pijcie z niego wszyscy”. Podczas każdej Eucharystii kapłan sprawujący ucztę paschalną jest zobowiązany do przyjęcia Komunii świętej, ale intencją Kościoła, zgodną z wolą Chrystusa, jest aby wszyscy znajdujący się w stanie łaski uświęcającej przyjmowali Komunię świętą (1 Kor 11, 27-32). Ona to bowiem włącza uczestników liturgii w komunię Kościoła w Bogu ${ }^{25}$.

$\mathrm{Na}$ nieszczęście, w historii Kościoła sytuacja nie zawsze układała się w ten sposób. Todopiero na początku poprzedniego wieku Komunia święta rozpoczyna odzyskiwać swoje uprzywilejowane miejsce w ramach Eucharystii. Dzięki dekretom eucharystycznym, wydanym za czasów papieża Piusa X, szerszy dostęp do Komunii eucharystycznej został otwarty wiernym świeckim i zakonnikom ${ }^{26}$. Jednak, cały wiek później, nie jesteśmy jeszcze pewni, czy Komunia święta

${ }^{23}$ Cérémonial desévêques, Paris 1998, 133; R. Le Gall, La messe au fil de ses rites, dz. cyt., s. 31-34.

${ }^{24}$ Mszał rzymski, dz. cyt., Dodatek, s. (5).

${ }^{25}$ P. De Clerck, Une mystagogie des rites de la communion, LMD 226 (2001), s. 151; R. Le Gall, La messe au fil de ses rites, dz. cyt., s. 189-190.

${ }^{26}$ Pius X, Decretum de dispositionibus requisitis ad frequentem et quotidianam Communionem eucharisticam sumendam Sacra Tridentina Synodus (16[20] XII 1905); ASS 38 (1905-1906), s. 400-406; Święta Kongregacja Sakramentów, Decretum de aetate admittendorum ad primam communionem eucharisticam Quam Singulari (8 VIII 1910), AAS 2 (1910), s. 577-583; por. A. Haquin, Les décrets eucharistiques de Pie X. Entre mouvement eucharistique et mouvement liturgique, LMD 203 (1995), s. 61-82. 
odzyskała już swoje miejsce, rozumiejąc jednocześnie, iż obrzędy Komunii, towarzyszące samej Komunii świętej, mają wydźwięk eklezjalny ${ }^{27}$.

Podobnie jak różne formy aktu pokutnego z obrzędów wstępnych Mszy świętej służą, aby nas przygotować do całej celebracji eucharystycznej, tak obrzędy towarzyszące Komunii świętej mają podobne zadanie w odniesieniu do tej części sprawowanej liturgii. Mówi o tym, w tych słowach, Ogólne wprowadzenie do Mszału rzymskiego:

„Ponieważ celebracja Eucharystii jest paschalną ucztą, wypada, aby zgodnie z nakazem Pana wierni należycie usposobieni przyjmowali Jego Ciało i Krew jako duchowy pokarm. Zmierza do tego łamanie oraz inne obrzędy przygotowawcze, które bezpośrednio prowadzą wiernych do Komunii świętej" (OWMR 80).

\subsubsection{Modlitwa Pańska}

Obrzędy Komunii rozpoczynają się modlitwą Pańską. Dla naszego tematu najważniejsza wydaje się być prośba o przebaczenie win: „Odpuść nam nasze winy, jako i my odpuszczamy naszym winowajcom”. Nie możemy prosić o miłosierdzie Boga, jeżeli nie czynimy go sami wobec naszych bliźnich, zgodnie z nauczaniem Chrystusa z przypowieści o nielitościwym dłużniku (Mt 18, 23-35). Prosimy o oczyszczenie z grzechów, „aby prawdziwie święci przyjmowali święte dary" (OWMR 81). Można jedynie dodać, iż prośba o przebaczenie win stanowi element łączący przekazywany sobie nawzajem znaku pokoju i przyjmowanej Komunii świętej.

Ponadto, jak zostało to podkreślone uprzednio, celebrowana Eucharystia posiada, między innymi, charakter pojednania, aby nas umocnić $\mathrm{w}$ życiu codziennym. To dodaje jeszcze bardziej siły formule kończącej modlitwę Pańską: "Ale nas zbaw ode złego". Ta prośba stanowi echo tej, którą sam Jezus zanosił w modlitwie kapłańskiej: „Nie proszę, abyś ich zabrał ze świata, ale byśich ustrzegł od złego" (J 17, 15). W końcu, fakt rozpoczęcia tej modlitwy słowami „Ojcze nasz" jest wybitnie symboliczny w tym momencie spotkania eucharystycznego, ponieważ celebrujemy komunię wszystkich uczestników liturgii wobec siebie pod przewodnictwem Chrystusa, ale również tę $\mathrm{z}$ całą ludzkością ${ }^{28}$.

Ostatnia prośba modlitwy Pańskiej jest rozbudowana $\mathrm{w}$ formie embolizmu wypowiadanego przez kapłana, a zakończeniem którego jest doksologia

${ }^{27}$ G. Pinckers, Communier avec dévotion, LMD 203 (1995), s. 58-60; P. De Clerck, Une mystagogie des rites de la communion, art. cyt., s. 152.

${ }^{28}$ A. Join-Lambert, Guide pour comprendre la messe, dz.cyt., s. 113-114; P. De Clerck, Une myslagogie des rites de la communion, art. cyt., s. 153. 
wypowiadana przez uczestników liturgii. Rozwinięcie ostatniej prośby modlitwy Pańskiej wydaje się być dobrym przejściem od tej ostatniej do znaku pokoju. Kościół uprasza, aby dzięki miłosierdziu Bożemu człowiek został uwolniony $\mathrm{z}$ więzów grzechu. Celebrowana liturgia eucharystyczna jest gwarancją najbardziej pewną naszej prawdziwej wolności, ponieważ czyni nas uczestnikami odkupieńczej ofiary. Jako owoc sprawowanej ofiary, wspólnota wierzących uprasza u Chrystusa dar prawdziwego pokoju i jedności w życiu codziennym. Prosimy o bezpieczeństwo w naszej wędrówce ku wieczności wobec czynników, które mogłyby zburzyć nasz pokój w Chrystusie. Sprawą oczywistą wydaje się być fakt, że prawdziwy pokój stanie się naszym udziałem w Królestwie niebieskim, gdy spotkamy Chrystusa przychodzącego z mocą i chwałą, którą opiewa doksologia embolizmu²9.

\subsubsection{Znak pokoju}

Po modlitwie Pańskiej wraz z embolizmem Mszał rzymski proponuje nam obrzęd pokoju. Otwiera się on modlitwą o pokój i jedność. Wraz z tą, która bezpośrednio poprzedza Komunię świętą jest to jedyna modlitwa skierowana do Chrystusa w całej celebracji eucharystycznej, w której prosimy: „Nie zważaj na grzechy nasze, lecz na wiarę swojego Kościoła”, abyśmy w rzeczywistości mogli lepiej wypełnić Jego wolę.

Myślimy tu spontanicznie o słowach Chrystusa: „Jeśli więc przyniesiesz dar swój przed ołtarz i tam wspomnisz, że brat twój ma coś przeciw tobie, zostaw tam dar swój przez ołtarzem, a najpierw idź i pojednaj się z bratem swoim. Potem przyjdź i dar swój ofiaruj!” (Mt 5, 23-24). To w tym duchu gest „pocałunku pokoju” rozumiany jest w liturgii od pierwszych wieków. Święty Paweł pisał do gmin chrześcijańskich w Rzymie, Koryncie i Tesalonikach o pozdrawianiu się „świętym pocałunkiem” (Rz 16, 16; 1 Kor 16, 20; 2 Kor 13, 12; 1 Tes 5, 26), to do tego gestu czyni również aluzje św. Piotr (1 P 5, 14). U Ojców Kościoła pocałunek pokoju stanowi dla wszystkich wiernych znak przebaczenia i pojednania ${ }^{30}$. Obrzęd pokoju dla chrześcijańskiego Wschodu i w rycie zairskim zachowuje do dziś dnia podobny charakter. Umieszczony w liturgii przed procesją z darami eucharystycznymi, jako gest pokutny, jest warunkiem owocnego przeżywania liturgii eucharystycznej, która następuje dopiero po nim ${ }^{31}$.

${ }^{29}$ R. Le Gall, La messe au fil de ses rites, dz. cyt., s. 195-198; L. Deiss, La messe. Sa célébration expliquée, dz. cyt., s. 124-126.

${ }^{30} \mathrm{M}$. Clavier, Eucharistie: la 'préparation pénitentielle' est-elle bien nécessaire, art. cyt., s. 127-130.

${ }^{31}$ P. De Clerck, L'»Ordo Missae" de Vatican II: ses innovations et sa réception, art. cyt., s. 187-188; wśród liturgistów podnoszą się głosy, aby przywrócić znakowi pokoju jego charakter pokutny wraz $\mathrm{z}$ umieszczeniem go bezpośrednio po litrugii słowa: H. Hollerweger, Ritus der Versöhnung mit Gott und den Brüdern: Schuldbekenntnis und Friedensgruß als Einheit, w: Bewahren und Erneuern: Studien zur Meßliturgie, dz. cyt., s. 274-284. 
W przeciągu wieków liturgia rzymska wydobyła znak pokoju z kontekstu pokutnego i włączyła go do obrzędów Komunii świętej. Nie jawi się on nam dzisiaj jako wyraźny gest pojednania, lecz bardziej jako pierwszy owoc akcji liturgicznej, która została dokonana ${ }^{32}$.

Ogólne wprowadzenie do Mszału rzymskiego wyjaśnia nam, że w znaku pokoju „Kościół prosi o pokój i jedność dla siebie samego i dla całej ludzkiej rodziny, wierni zaś okazują sobie trwającą w Kościele komunię i miłość, zanim przyjmą Najświętszy Sakrament" (OWMR 82). Znak pokoju posiada ogromne znaczenie teologiczne i symboliczne. Wiemy, że ten pokój nie ogranicza się jedynie do braku wojny, ale jest uwieńczeniem całego procesu pojednania. To shalom biblijny, dar mesjański najbardziej doskonały (Łk 2, 14) i owoc pozdrowienia paschalnego zmartwychwstałego Zbawiciela (J 20, 19.21.26) ${ }^{33}$.

Obrzęd pokoju oznacza przyjęcie przez każdego uczestnika zgromadzenia liturgicznego pokoju, który pochodzi od Chrystusa umęczonego, zmarłego, ale zmartwychwstałego. Taki charakter podkreślają słowa celebransa, który zachęca: „Pokój Pański niech zawsze będzie z wami”. Chrystus podczas każdej Eucharystii obdarza nas swoim pokojem, abyśmy mogli go dzielić i nim żyć razem z braćmi. Pokój jest manifestacją konkretną nowego życia. Jest owocem nawracania, które dokonywać się winno bezustannie, ponieważ prawdziwy uczeń Jezusa powinien być nieustannie „in statu conversionis”34. W ten sposób znak Chrystusowego pokoju, odnawiany podczas każdej Eucharystii, umacnia nas, podobnie jak ona sama. W rzeczywistości, przed samym przyjęciem „ciała wydanego i krwi przelanej” naszego Zbawiciela, jesteśmy zaproszeni do przyjęcia i podzielenia się pokojem Chrystusowym. Jak zauważa słusznie Paul De Clerck: „Otrzymać pokój i dalej go przekazać, jest to (...) już jakaś forma Komunii”, abyśmy mogli wspólnie z Chrystusem podążać drogą naszego życia ${ }^{35}$.

${ }^{32}$ Kongregacja Kultu Bożego i Dyscypliny Sakramentów, Instrukcja Redemptionis sacramentum, 71; P. De Clerck, Le geste de paix: usages et significations, w: Liturgie et charité fraternelle, A. M. Triacca, A. Pistoia (red.), Roma 1999, s. 110.

${ }^{33}$ P. De Clerck, Le geste de paix : usages et significations, art.cyt., s. 97-98; tenże, Une théologie dela liturgie. „Pour la gloire de Dieu et le salut du monde”, LMD 221 (2000), s. 25.

${ }^{34}$ Jan Paweł II, Encyklika Dives in misericordia, 13.

${ }^{35}$ Por. A. Join-Lambert, Guide pour comprendre la messe, dz. cyt., s. 115-116; zaskakujące wydają się być słowa zaproszenia do dzielenia się pokojem Mszału niemieckiego: „Przekażcie sobie znak pokoju i pojednania [Gebt einander ein Zeichen des Fridens und der Versöhnung]”; ostatnie słowo stanowi rozszerzenie $\mathrm{w}$ porównaniu $\mathrm{z}$ oryginałem łacińskim. Być może autorzy tłumaczenia niemieckiego chcieli podkreślić charakter pojednawczy znaku pokoju, który tak bardzo chcieli przenieść na zakończenie liturgii słowa, odwołując się do tradycji niemieckiej - Offene Schuld: B. Kranemann, Die Versöhnung mit Gott und den Menschen in der Feier der Gemeindemesse: Zum Ort des Bußaktes im Ordo Missae, „Heiliger Dienst" 51 (1997), s. 103-105; można się jedynie dopytywać czy poszerzenie to, po reformie Pawła VI, ma jeszcze rację bytu, wszakże zmienia całkowicie charakter całego obrzędu pokoju: P. De Clerck, Une mystagogie des rites de la communion, LMD 226 (2001), s. 154-155. 


\subsubsection{Baranku Boży}

Po znaku pokoju następuje łamanie chleba i ryt zmieszania Świętych Postaci. Tradycyjnie łamaniu chleba towarzyszy śpiew Baranku Boży. Słowa tej inwokacji sięgają swoimi korzeniami wskazaniu Jana Chrzciciela, który w ten właśnie sposób określił Jezusa ukazując Go swoim uczniom (J 1, 29). Niemniej jednak godny uwagi jest motyw baranka przewijający się przez całą Biblię. Rozpoczynając od Abla ofiarującego Bogu pierwociny ze swojej trzody (Rdz 4, 4) aż do dwudziestu ośmiu wzmianek Chrystusa jako Baranka w Apokalipsie. Jeżeli natomiast chodzi o nasz tekst, dwie sceny są bardzo znaczące. Najpierw zarządzenie dotyczące ofiary z baranka paschalnego z Księgi Wyjścia podczas ucieczki z Egiptu. Ta właśnie ofiara będzie powtarzana każdego roku jako pamiątka uwolnienia narodu wybranego $\mathrm{z}$ niewoli faraona (Wj 12, 1-14). Następnie pieśń cierpiącego sługi Jahwe z Księgi proroka Izajasza: nowego Baranka, który przez swoją śmierć odnowi Stare Przymierze (Iz 53, 6-7) ${ }^{36}$.

Należy zauważyć jednocześnie, iż inwokacja Baranku Boży znajduje się w dosłownym brzmieniu w "hymnie anielskim” Chwała na wysokości Bogu, wcześniej wzmiankowanym. Jest ona $\mathrm{w}$ tym momencie powtórzona przez liturgię eucharystyczną $\mathrm{w}$ perspektywie ofiary $\mathrm{z}$ baranka paschalnego. Liturgia niebieska, opisywana przez Apokalipsę, jest więc obecna na naszych ołtarzach. Upraszamy zwycięskiego Baranka, aby zmiłował się nad nami i pozwolił nam skorzystać $\mathrm{z}$ daru swego pokoju.

Zaproszenie celebransa, odwrócone $\mathrm{w}$ języku francuskim, podejmuje następnie słowa inwokacji Baranku Boży, dodając błogosławieństwo inspirowane słowami Apokalipsy: „Błogosławieni, którzy są wezwani na ucztę Godów Baranka" (Ap 19, 9). Pojednani przez ofiarę baranka paschalnego, jesteśmy wybrani przez Pana i dopuszczeni do Jego uczty. Zgromadzenie Kościoła, odpowiadając na to zaproszenie, podejmuje z niewielką zmianą słowa setnika rzymskiego z Kafarnaum, wyznającego w następujący sposób swoją wiarę w Chrystusa (Mt 8, 8): „Panie, nie jestem godzien, abyś przyszedł do mnie, ale powiedz tylko słowo, a będzie uzdrowiona dusza moja”. „Godność”, o której mówi setnik nie jest $\mathrm{z}$ serii zagadnień moralnych, ale uznania stanu powszechnej grzeszności ludzkości, a więc niegodności wobec wszelkiej świętości, a przede wszystkim Boga. Poprzez tę ostatnią modlitwę przed przyjęciem Komunii świętej zgromadzona wspólnota potwierdza swoje zaufanie wobec tego, który przebacza, a z którym w tym momencie chce się zjednoczycic ${ }^{37}$.

${ }^{36}$ R. Le Gall, La messe au fil de ses rites, dz. cyt., s. 204-205.

${ }^{37}$ B. de Boissieu, Eucharistie et pénitence, art. cyt., s. 575; A. Join-Lambert, Guide pour comprendre la messe, dz. cyt., s. 116-118. 
Poza momentami celebracji eucharystycznej, które zostały powyżej przedstawione, odnaleźć możemy inne jeszcze aspekty pojednania w formułach modlitw wypowiadanych w ciszy jedynie przez głównego celebransa.

\subsection{Apologie w celebracji eucharystycznej}

Poprzez apologie rozumiemy "wyznanie i modlitwę o charakterze pokutnym", wypowiadaną prywatnie przez kapłana podczas Eucharystii. Adrian Nocent przypuszcza, że pierwsze apologie kapłańskie są pochodzenia galijskiego, albo przynajmniej należy zauważyć, iż to właśnie w liturgii gallikańskiej pojawiały się one i rozwijały począwszy od IX stulecia. Możemy zaobserwować stopniowy rozwój tych modlitw w wieku X i XI, a następnie stopniowe ich zanikanie. Motywem, który bez wątpienia powstrzymał rozwój apologii jest pojawienie się - u schyłku XI stulecia - wspólnotowego aktu pokuty wraz $\mathrm{z}$ rozgrzeszeniem. W rzeczywistości, pojawienie się dyskretne apologii, rozkwit, a następnie gwałtowne zaniknięcie, korespondują dobrze $\mathrm{z}$ poszczególnymi etapami dyscypliny i teologii sakramentu pokuty.

Apologie reprezentują dość specyficzną formę liturgiczną. Ich charakter prywatny jest wyraźnie zaakcentowany $\mathrm{w}$ ich sformułowaniu poprzez użycie pierwszej osoby liczby pojedynczej. Są adresowane do Chrystusa albo Trójcy Świętej i są pewnego rodzaju oryginalnością w liturgii rzymskiej. Były bardziej obecne w poprzednim Ordo missae Piusa V, z okresu przed reformą Mszału Pawła VI ${ }^{38}$.

\subsubsection{Apologie Ewangelii}

Głoszenie Ewangelii podczas Mszy świętej uważa się za szczyt liturgii słowa. Sobór Watykański II naucza: „Jest obecny [Chrystus] w swoim słowie, albowiem gdy w Kościele czyta się Pismo święte, wówczas On sam mówi" (Sacrosanctum Concilium 7). Lektura Pisma świętego nie była nigdy, czy to w liturgii synagogalnej, czy też w liturgii chrześcijańskiej, jedynie prostym czytaniem księgi opisującej historię ludu wybranego. Czytanie Ewangelii jest bardziej celebracją samego Chrystusa. To właśnie z tego powodu lektura ta była zawsze otoczona niezwykłym szacunkiem (OWMR 60).

Pośród obrzędów towarzyszących głoszeniu Ewangelii możemy odnaleźć modlitwę prywatną kapłana, poprzez którą, pod nieobecność diakona,

${ }^{38}$ A. Nocent, Les apologies dans la célébration eucharistique, w: Liturgie et rémission des péchés, A. Pistoia, A. M. Triacca (red.), Roma 1975, s. 179-196; Apologies du prêtre, w: Nuovo Dizionario di Liturgia, D. Sartore, A. M. Triacca (red.), Roma 1984, tłum. franc. H. Delhougne (red.), t. 2, Brepols 2002, s. 510. 
przygotowuje się następującymi słowami do głoszenia Dobrej Nowiny: „Wszechmogący Boże, oczyść serce i usta moje, abym godnie głosił Twoją świętą Ewangelię".

„Oczyszczenie” kapłana, głoszącego słowa Chrystusa, dokonuje się przez misterium paschalne już dokonane $\mathrm{w}$ Chrystusie, który jest nam głoszony w słowach Ewangelii. Obecność ofiary pojednania, dokonanej w sposób krwawy na krzyżu, jest zaznaczona poprzez mały znak krzyża, uczyniony na księdze przez czytającego na początku przewidzianej perykopy ewangelijnej. Następnie podobny znak krzyża czyni całe zgromadzenie liturgiczne na czole, ustach i klatce piersiowej. Gest ten oznacza, iż misterium pojednania Chrystusa ukrzyżowanego i zmartwychwstałego, ogłaszane nam w Ewangelii, powinno zapisać się jak najgłębiej w naszych myślach, być wyrażane poprzez nasze słowa, aby w końcu zamieszkało naprawdę w naszych sercach ${ }^{39}$.

Wreszcie charakter pojednawczy słów głoszonej Ewangelii jest potwierdzony poprzez inną apologię, wypowiadaną przez diakona lub kapłana, gdy ten ostatni zakończy czytanie słów Pańskich. Po odpowiedzi zgromadzenia liturgicznego, w momencie ucałowania księgi Ewangelii, czytający modli się: „Niech słowa Ewangelii zgładzą nasze grzechy"40. Oznaki szacunku towarzyszące tej lekturze świadczą wymownie o doniosłości głoszonej Ewangelii, w której słuchamy samego Chrystusa, przemawiającego w zgromadzeniu liturgicznym.

\subsubsection{Apologie przygotowania darów ofiarnych}

Starożytne ofertorium jest momentem uprzywilejowanym dla modlitw prywatnych celebransa. Ale równocześnie, jak zauważa Robert Cabié, jest to również „miejsce największych różnic lokalnych, utrwalonych poprzez ryty, które przetrwały reformę Piusa $V^{\prime \prime 1}$. Nowe Ordo, zreformowane przez Pawła VI, nie zachowało większości starych apologii. Zainteresujemy się jedynie dwoma ostatnimi, które towarzyszą obmyciu rąk kapłana celebrującego Eucharystię.

Najpierw ksiądz, pochylony przed ołtarzem w geście uniżenia, wypowiada po cichu następujące słowa: „Przyjmij nas, Panie, stojących przed Tobą $\mathrm{w}$ duchu pokory i z sercem skruszonym; niech nasza ofiara tak się dzisiaj dokona przed Tobą, Panie Boże, aby się Tobie podobała”. Formuła ta jest zainspirowana fragmentem proroka Daniela, z kantyku Azariasza w piecu ognistym (Dn 3,

${ }^{39}$ T. Sinka, Zarys liturgiki, Kraków 2003, s. 82-83; Gesty liturgiczne. Wydanie studyjne, T. Powichrowski, A. Salamucha (red.), Kraków 1996, s. 14-15.

${ }^{40}$ J. A. Jungmann, Missarum Sollemnia, dz. cyt., t. 2, s. 221; P. De Clerck, Le salut, ou la réconciliation et ses réalisations sacramentelles, art. cyt., s. 38; R. Le Gall, La messe au fil de ses rites, dz. cyt., s. 82-84.

${ }^{41}$ Por. A. G. Martimort, L'Église en Prière, dz. cyt., t. 2, s. 174-182. 
37-40 ${ }^{42}$. Zanim zostanie złożona Bogu ofiara nowego i wiecznego Przymierza, kapłan uznaje swoją niegodność. Ale jednocześnie jest on w pełni świadomy, że Bóg nie odtrąci nigdy serca przenikniętego pokorą i zaufaniem. Poprzez gest pełen ufności kapłan usuwa się przed wielkością ofiary Chrystusa, stwarzając $\mathrm{w}$ ten sposób prawdziwą podstawę całej modlitwy. Uznanie swojego grzesznego stanu nie osłabia go, a wręcz przeciwnie, umacnia jego życie chrześcijańskie.

W następnym geście, czy też po okadzeniu, o ile takowe następuje, kapłan obmywa z boku ołtarza swoje ręce. Ryt ten wyraża chęć oczyszczenia wewnętrznego. Słowa, które towarzyszą obmyciu uświadamiają dobrze fakt niemożliwości zbliżenia się do Boga bez uprzedniego oczyszczenia się z grzechów. Mszał przytacza następujące słowa, wypowiadane przez kapłana: „Obmyj mnie, Panie, z mojej winy i oczyść z grzechu mojego”. Poprzez te słowa, zaczerpnięte z psalmu Miserere mei Deus [51(50), 4], celebrans główny zaznacza, że jest takim samym grzesznikiem jak inni ochrzczeni, a więc że nie znajduje się bynajmniej przy ołtarzu ze względu na swe zasługi czy też posiadane zdolności. To tylko dzięki łasce, którą otrzymał podczas święceń kapłańskich, może dokonać tej świętej przemiany w imieniu zgromadzonej wspólnoty, uczestniczącej w Eucharystii na swój własny sposób ${ }^{43}$.

\subsubsection{Apologie obrzędów Komunii świętej}

Przedstawiliśmy powyżej elementy obrzędów Komunii świętej, które mają wydźwięk pojednania ( $\$ 1.2$ ). Wśród nich pozostała jednak jeszcze modlitwa prywatna celebransa, poprzez którą „kapłan przygotowuje się do owocnego przyjęcia Ciała i Krwi Chrystusa" (OWMR 84). Mszał rzymski daje nam możliwość wyboru jednej z dwóch modlitw przygotowujących.

Pierwsza formuła sięga swoją historią IX w., kapłan modli się w niej - „Panie Jezu Chryste (...) za współdziałaniem Ducha Świętego” - o wybawienie, za pośrednictwem Ciała i Krwi Chrystusa, z niewoli grzechu i od wszelkiego zła, podobnie jak prosiliśmy w ostatniej prośbie modlitwy Pańskiej. Dzięki Komunii świętej pozostajemy w jedności z Chrystusem w naszym życiu codziennym, zanim się z Nim złączymy w Jego Królestwie. Komunia święta pomaga nam żyć po chrześcijańsku w praktykowaniu przykazań Bożych, dzięki czemu pozostajemy złączeni w miłości Chrystusa $(J 15,10)$.

W drugiej modlitwie, która może być użyta przez kapłana w ramach przygotowania do przyjęcia Komunii świętej, modli się on: „Panie Jezu Chryste,

${ }^{42} \mathrm{R}$. Le Gall, La messe au fil de ses rites, dz. cyt., s. 117-118.

${ }^{43}$ J. A. Jungmann, Missarum Sollemnia, dz. cyt., t. 2, s. 354-360; A. Join-Lambert, Guide pour comprendre la messe, dz. cyt., s. 96-97. 
niech przyjęcie Ciała i Krwi Twojej nie ściągnie na mnie wyroku potępienia, lecz dzięki Twemu miłosierdziu niech mnie chroni oraz skutecznie leczy moją duszę i ciało". Eucharystia nie jest nagrodą zarezerwowaną ludziom idealnym, ale jest pokarmem i lekarstwem dla tych, „którzy łakną i pragną sprawiedliwości” (Mt 5, 6). Jednocześnie nie wolno nam banalizować rzeczywistości eucharystycznej, która wymaga godnego przygotowania do przyjęcia Komunii świętej, zwłaszcza w przypadku grzechu śmiertelnego, ciążącego na naszym sumieniu. Taka sytuacja wymagałaby pojednania z Chrystusem przez sakrament pokuty i pojednania, zanim zechcemy przystąpić do stołu Pańskiego (1 Kor 11, 27-29). Dlatego też kapłan prosi: „Niech przyjęcie Ciała i Krwi Twojej, nie ściągnie na mnie wyroku potępienia"44.

W przygotowaniu kapłana do przyjęcia Komunii świętej w słowach: „Wybaw mnie przez najświętsze Ciało i Krew Twoją od wszystkich nieprawości moich i od wszelkiego zła", podobnie jak w tych, które kapłan wypowiadał w momencie ucałowania księgi Ewangelii, po odczytaniu perykopy ewangelijnej: „Niech słowa Ewangelii zgładzą nasze grzechy”, zauważyć można jedność dwóch "stołów” występujących w Eucharystii. Realizacja Słowa Bożego, usłyszanego w liturgii słowa, jak i przyjęcie Komunii świętej mają służyć naszemu zbawieniu. Dobra Nowina, obiecująca nam przebaczenie grzechów, jest pewna, natomiast Komunia święta, dająca udział w Ciele i Krwi Zbawiciela, potwierdza ten fakt i daje nam udział w rzeczywistości niebiańskiej, która nas zjednoczy z Chrystusem zmartwychwstałym ${ }^{45}$.

\subsection{Terminologia pojednania w Missale romanum 2002}

Liczba wystąpień terminu „pojednanie” wraz z pochodnymi powiększyła się w trzecim wydaniu typicznym Mszału rzymskiego w porównaniu z wydaniami poprzednimi. Począwszy od ośmiu wystąpień w pierwszej edycji Missale romanum wyrażenie to występuje aż dwadzieścia jeden razy w ostatniej wersji typicznej Mszału rzymskiego ${ }^{46}$.

Znaczny wzrost terminologii pojednania spowodowany jest przede wszystkim wprowadzeniem do nowej edycji typicznej nowych modlitw eucharystycznych. Siedem wystąpień terminu "pojednanie” w modlitwach eucharystycznych o tajemnicy pojednania oraz jedno w drugiej modlitwie eucharystycznej w Mszach

${ }^{44} \mathrm{R}$. Le Gall, La messe au fil de ses rites, dz. cyt., s. 205-209.

${ }^{45}$ B. de Boissieu, Eucharistie et pénitence, art. cyt., s. 575.

${ }^{46}$ Por. M. Sodi, A. Toniolo, Concordantia et Indices Missalis Romani. Editio typica tertia, Città del Vaticano, 2002, s. 1430-1431; Concordantia verbalia Missalis Romani. Partes euchologicae, T. A. Schnitker, W. A. Slaby (red.), Münster 1983, kol. 2141-2142. 
z udziałem dzieci podwajają już częstotliwość początkową. Ponadto, wprowadzenie nowych formularzy Mszy świętych, związanych $\mathrm{z}$ dodaniem nowych Mszy wotywnych i w różnych potrzebach, zwiększyło obecność pojęcia pojednania w słownictwie Mszału rzymskiego ${ }^{47}$.

\subsubsection{Bóg Ojciec jako źródło pojednania}

Przedstawiając aspekt trynitarny naszych dwóch MEP podkreśliliśmy już rolę wiodącą Boga Ojca $w$ procesie pojednania. On jest tym, który jest źródłem wszelkiego wysiłku zdążającego do pokoju (Pref, II MEP), jest celem pojednania. Antyfona na wejście jednej z Mszy wspólnych o Najświętszej Maryi Pannie uprasza, aby Bóg przywrócił pokój, pojednawszy się z nami ${ }^{48}$. W rzeczywistości człowiek, oddalony od Boga przez grzech, nie jest w stanie sam powrócić do Stwórcy. To Bóg czyni nas gotowymi do pojednania (Pref, II MEP) i doprowadza nas na nowo do swojej miłości (PSct, II MEP) przez swojego Syna wydanego w ręce ludzkości.

Bóg nie zmusza nigdy człowieka. Fakt ten dobrze oddaje kolekta Mszy świętej o pojednanie: „Boże, Ty litujesz się i przebaczasz, Ty dajesz ludziom dni zbawienia, aby uznali w Tobie Stwórcę i Ojca wszystkich". Czas pojednania i pokoju (Pref, I MEP) już nadszedł, ludzkość otrzymała tak długo oczekiwanego Zbawiciela. W sposób szczególny $\mathrm{w}$ naszych uroczystościach przeżywamy na nowo pamiątkę naszego odkupienia, ale każda Eucharystia aktualizuje misterium naszego zbawienia. Może czasem zapominamy, iż to $\mathrm{z}$ naszej strony Bóg oczekuje większego zaangażowania. Nawet jeśli nie jesteśmy zdolni ocalić naszego kruchego życia, nie tracimy nadziei i wołamy: „Pomóż nam w tym czasie łaski, abyśmy otwartym sercem przyjęli słowo pokoju i zgodnie z Twoją wolą starali się pojednać wszystko w Chrystusie"'49.

Bóg Ojciec dokonał swego dzieła pojednania posyłając nam swojego Syna, jak modlimy się z kolektą czwartej niedzieli Wielkiego Postu: „Boże, Ty za pośrednictwem swojego Syna pojednałeś ludzkość ze sobą”. Misja Zbawiciela jest kontynuowana w Kościele przez Niego założonym, bo to On przedłuża obecność Chrystusa pośród swego ludu. To my mamy teraz zaangażować się w to dzieło

${ }^{47}$ Por. Commune Beatae Mariae Virginis - I. Tempore "per annum« nr 6, Ant. ad Introitum, s. 902. Ss. Cyrilli, monachi, et Methodii, episcope, Super oblata, s. 727. Missae rituales in conferendis sacris ordinibus - 2. In ordinatione presbyterorum - A. In Ordinatione plurium presyterorum; B. In Ordinatione unius presbyteri, Benedictio in fine Missae, s. 1006. Feria quinta - Tempus paschale in feriis post dominicam II Paschae, Collecta, s. 391.

${ }^{48}$ Commune Beatae Mariae Virginis, I. Tempore »per annum«n 6 , Ant. ad introitum, MR 2002, s. 902.

${ }^{49}$ Pro reconciliatione, collecta, MR 2002, s. 1109; Mszał rzymski, dz. cyt., s. 150. 
zbawcze, nawet jeśli czujemy się nie do końca zdolni, modlimy się: „Spraw, aby lud chrześcijański z żywą wiarą i szczerym oddaniem" wypełniał do końca swoje posłannictwo pojednania wszystkiego w Chrystusie $(2 \text { Kor 5, 20 })^{50}$.

\subsubsection{Chrystus przynoszacy pojednanie}

Obciążony wypełnianiem misji powierzonej przez Ojca, Jezus staje się naszym Zbawicielem. Dzięki jego ofierze wszyscy ludzie mogą korzystać $\mathrm{z}$ wolności dzieci Bożych. Chrystus stał się bowiem "naszym pokojem i pojednaniem”, kiedy „krwią swoją zgładził grzech świata”'

Jezus był całkowicie świadomy swojej odpowiedzialności za ciężkie jarzmo złożone na jego barki. Dźwigał je do końca i nam zostawił pamiątkę tego wydarzenia. Podobnie jak On na Ostatniej Wieczerzy, „wiedząc, że pojedna wszystko w sobie przez krew wylaną na krzyżu" (Rec, I MEP), wypełniamy te same gesty i wypowiadamy Jego własne słowa, jedząc i pijąc z kielicha jego Krwi, która została wylana za nas i za wielu na odpuszczenie grzechów.

Jezus stał się kapłanem, w całym tego słowa znaczeniu, jedynej ofiary pojednania, a do tego wtedy, gdy my byliśmy jeszcze grzesznikami $(\operatorname{Rz} 5,8)$. Bóg uczynił go grzechem dla nas, abyśmy my i nam podobni, stali się w Nim sprawiedliwością Bożą i dostąpili łaski zmartwychwstania (2 Kor 5, 21) $)^{52}$. Bóg nas tak ukochał, że „posłał Syna swojego jako ofiarę przebłagalną za nasze grzechy” (1 J 4, 10). Jezus, Zbawiciel świata, posłuszny woli Ojca „wydał się sam w nasze ręce, aby stać się żertwą pojednania i pokoju w naszej ofierze oraz aby nas pociągnąć” do Boga swojego Ojca ${ }^{53}$.

Wspominamy teraz naszą opłakaną grzeszną sytuację, kiedy modlimy się nad darami ofiarnymi Mszy świętej za tych, którzy nas trapią: „wspominamy śmierć Twojego Syna, przez którą pojednałeś nas ze sobą, chociaż byliśmy Twoimi nieprzyjaciółmi" ${ }^{54}$.

Ofiara sprawowana w naszych zgromadzeniach liturgicznych, jako aktualizacja jedynej ofiary naszego Pana, oddaje nas w ręce Stworzyciela. Jednocześnie, gdy celebrujemy misterium pojednania, przyniesionego nam przez Chrystusa (Ep, II MEP), prosimy Boga Ojca, aby nas samych uświęcił wraz $\mathrm{z}$ ofiarą złożoną na ołtarzu.

\footnotetext{
${ }^{50}$ Dominica IV in Quadragesima, collecta, MR 2002, s. 240; Mszał rzymski, dz. cyt., s. 90.

${ }^{51}$ Pro reconciliatione, collecta, MR 2002, s. 1109; Mszał rzymski, dz. cyt., s. 150'.

${ }^{52}$ Feria quinta - Tempus paschale in feriis post dominicam II Paschae, collecta, MR 2002, s. 391; Mszał rzymski, dz. cyt., s. 198.

${ }^{53}$ Prex eucharistica II pro missis cum pueris, anamnese, MR 2002, s. 1280.

${ }^{54}$ Pro affligentibus nos, super oblata, MR 2002, s. 1144; Msza za tych, którzy nas trapiq, Mszat rzymski, dz. cyt., s. 177.
} 


\subsubsection{Ofiara pojednania}

Pojęcie ofiary pojednania jest najbardziej obecne $\mathrm{w}$ nowym wydaniu Mszału rzymskiego. Wspólnota eucharystyczna może radować się z możliwości celebrowania „ofiary doskonałego pojednania” (An, II MEP), którą daje nam Pan. Kościół ma świadomość tegoż wymiaru, gdy modli się $\mathrm{w}$ anamnezie pierwszej modlitwy eucharystycznej o tajemnicy pojednania: „składamy Ci, Boże prawdziwy i wierny, tę Ofiarę, która całej ludzkości daje pojednanie z Tobą”.

Ludzkość oddalona przez grzech od Przymierza ze swoim Stworzycielem zanosi modlitwę: „przyjmij z upodobaniem Ofiarę, przez którą dokonało się nasze pojednanie $\mathrm{z}$ Tobą, i spraw, aby wzniosła się do Ciebie jako doskonałe uwielbienie" 55 . Bez pomocy Boga, wiecznego i wszechmocnego, człowiek nie potrafiłby uwolnić się ze swego żałosnego położenia. Na szczęście, Bóg „przez misterium paschalne pojednał ludzkość ze sobą i zawarł z nią nowe przymierze”. Teraz człowiek chciałby okazywać w całym swoim życiu owoce misterium, które przeżywał $\mathrm{z}$ wiarą ${ }^{56}$.

W rzeczywistości, ofiara pojednania powinna nas doprowadzić do doskonałej jedności i pokoju, jak wyraża to doskonale modlitwa nad darami z uroczystości Chrystusa Króla Wszechświata: „Panie, nasz Boże, składamy Tobie Ofiarę pojednania i pokornie Cię błagamy, aby Twój Syn udzielił wszystkim narodom darów jedności i pokoju"s7. W perspektywie życia wiecznego, gdzie będziemy się radować pełnią pokoju, Eucharystia zanurza nas w zbawienie, które staje się naszym udziałem już tu w Kościele ziemskim, gdy prosimy: „Aby ta Ofiara naszego pojednania z Tobą, sprowadziła na cały świat pokój i zbawienie" (Mw, III ME).

W każdym bądź razie, Eucharystia sprawowana jako ofiara, na pamiątkę tej jedynej ofiary Chrystusa, daje nam już dostęp do uczty niebieskiej i czyni ze zgromadzonych wiernych nowy lud Boży, jak czytamy w modlitwie nad darami, przeżywając święto św. Cyryla i Metodego, patronów Europy: „Boże, wejrzyj na dary, które składamy Twojemu majestatowi (...), spraw, aby się stały znakiem nowej ludzkości pojednanej z Tobą przez miłość" 58 .

Jedynie jedno wystąpienie pojęcia pojednania w Mszale rzymskim jest związane z sakramentem pokuty i pojednania. W Mszy świętej obrzędowej przy udzielaniu święceń biskupa lub kapłanów, w uroczystym błogosławieństwie na

${ }^{55}$ Nativitas Domini, super oblata, MR 2002, s. 160; Mszał rzymski, dz. cyt., s. 36.

${ }^{56}$ Feria VI infra Octavam Paschae, collecta, MR 2002, s. 384; Mszat rzymski, dz. cyt., s. 190.

${ }^{57}$ Domini nostri Iesu Christi Universorum Regis, super oblata, MR 2002, s. 496; Mszat rzymski, dz. cyt., s. 281.

${ }^{58}$ Ss. Cyrilli, monachi, et Methodii, episcopi, super oblata, MR 2002, s. 727; Mszał rzymski, dz. cyl., s. 22. 
zakończenie Eucharystii, celebrans prosi, aby wyświęceni stali się w świecie sługami miłości i prawdy, a także wiernymi szafarzami pojednania ${ }^{59}$.

Możemy podsumować, iż w nowej edycji Mszału rzymskiego pojęcie pojednania jest o wiele bardziej obecne w odniesieniu do wydań wcześniejszych. Odnosi sięono przede wszystkim do waloru pojednawczego uczty eucharystycznej, który został nam dany przez Boga Ojca i dopełniony w ofierze Jego Syna, Jezusa Chrystusa. Ofiara eucharystyczna, sprawowana w naszych wspólnotach na pamiątkę wydarzenia paschalnego Zbawiciela, przynosi nam jedność i pokój. Jeszcze bardziej podkreślają tę rzeczywistość modlitwy eucharystyczne o tajemnicy pojednania. Zechciejmy zapoznać się bliżej $\mathrm{z}$ elementami mistagogii tych modlitwy, aby mogły stać się jeszcze pełniejszą modlitwą zgromadzenia liturgicznego.

\section{Mistagogia modlitw eucharystycznych o tajemnicy pojednania}

Dominico Sartore, w swojej publikacji z 1994 r., podkreśla z zadowoleniem, że starożytne pojęcie „mystagogii” w ostatnich latach odnajduje swój dawny blask i miejsce w teologii Kościoła ${ }^{60}$. Według niego ta „koniunktura mistagogiczna” powinna zainteresować liturgię, katechezę, homiletykę i pedagogikę, czy też całą teologię pastoralną ${ }^{61}$. Chociaż termin ten zainteresował już kilka osobistości z ruchu liturgicznego ${ }^{62}$ i pojawił się w kilku oficjalnych dokumentach Kościo$\mathfrak{ł a}^{63}$ wydaje się, że nie odzyskał jeszcze swego splendoru z tradycji patrystycznej. Nieobecność opracowania tego terminu w Słowniku encyklopedycznym liturgii ${ }^{64}$,

${ }^{59}$ Missae rituales in conferendis sacris ordinibus - 2. In ordinatione presbyterorum - A. In Ordinatione plurium presyterorum; B. In Ordinatione unius presbyteri, benedictio in fine Missae, MR 2002, s. 1006.

${ }^{60}$ D. Sartore, Mistagogia ieri e oggi: alcune pubblicazioni recenti, „Ecclesia Orans” 11 (1994), s. 181-199.

${ }^{61}$ E. Bargellini, Catechesi e liturgia: è ancora attuale il metodo mistagogico dei padri?, „Vita Monastica” 28 (1974), nr 116-117, s. 37-67; D. Sartore, La mistagogia, modello e sorgente di spiritualità cristiana, „Rivista Liturgica” 73 (1986), s. 508-521; P. M. Gy, La liturgie entre la fonction didactique et la mystagogie, LMD 177 (1989), s. 7-18; G. Pinckers, Le temps de la mystagogie, w: Dans vos Assemblées, Manuel de pastorale liturgique, J. Gelineau (red.), Tournai 1998, s. 293-300; D. Emeis, Sakramentenkatechese als mystagogische Symboldidaktik, „Bibel und Liturgie” 64 (1991), s. 179-186.

${ }_{62}$ P. M. Gy, La mystagogie dans la liturgie ancienne et dans la pensée liturgique d'aujourd'hui, w: Mystagogie: pensée liturgique d'aujourd'hui et liturgie ancienne, A. M. Triacca, A. Pistoia (red.), Roma 1993, s. 138-142.

${ }^{63}$ Rituel de l'initiation chrétienne des adultes, Paris 1997, nr 236-243; por. A. M. Triacca, Terminologie initiatique ou mystagogique selon le rituel de l'initiation chrétienne des adultes, w: Mystagogie, dz. cyt., s. 329-350. KKK, nr 1075, 1234-1245; Jan Paweł II, List Apostolski Mane Nobiscum Domine, 17.

${ }^{64}$ Dictionnaire encyclopédique de la liturgie (dalej skrót: DEL), H. Delhougne (red.), t. 1-2, Brepols 1992-2002, oprócz krótkiej noty leksykalnej (s. 545). 
czy też absencja we współczesnym nauczaniu Kościoła świadczą o niewystarczającym rozwoju myśli mistagogicznej w teologii nowożytnej Kościoła.

W epoce patrystycznej termin „mistagogia” posiadał trzy podstawowe znaczenia, nie wspominając, iż $\mathrm{w}$ terminologii aleksandryjskiej posiadał przede wszystkim charakter duchowy. Można je wyróżnić i nazwać od imion własnych ich głównych przedstawicieli, toteż mówimy o mistatogii św. Chryzostoma, św. Cyryla i Dionizego. Pierwsza mistagogią nazywa celebrację sakramentów inicjacji chrześcijańskiej. Mistagogia w rozumieniu św. Cyryla Jerozolimskiego, tak prężnie rozwijająca się po Soborze Watykańskim II, jest rozumiana jako katecheza, podczas której wyjaśnia się i pogłębia znaczenie sakramentów wcześniej przyjętych. Ostatnia, związana z Pseudo-Dionizym Areopagitą, inspirowana i karmiona doświadczeniem chrześcijańskim, rozwija teologię sakramentów i liturgii ${ }^{65}$.

W dobie współczesnej, w pełni korzystając z modeli i sensu mistagogii klasycznej, trzeba nam szukać „nowej formy mistagogii”, bardziej dostosowanej do współczesnego Kościoła, aby wzbogacić zarówno teologię, jak i duchowość naszych celebracji.

Wyjaśnienie sensu mistagogicznego rytu liturgicznego i słów własnych modlitw eucharystycznych o pojednaniu, pomogą nam przeniknąć ostatecznie do głębi bogactwa misterium przeżywanego w celebracji eucharystycznej ${ }^{66}$. Ważnym celem tej części pracy jest przybliżenie naszej modlitwie treści zawartych w MEP, które, niestety, niezbyt często są wykorzystywane w liturgii Kościoła. Proponowane modlitwy rozważamy oddzielnie ze względu na inne traktowanie pojęcia pojednania przez każdą z nich.

\subsection{Pogłębienie mistagogiczne I MEP}

W I MEP tematyka pojednania jest bardzo mocno inspirowana Pismem świętym. Ta zależność, jak czytaliśmy w poprzednich częściach pracy, rzuca pewne światło na koncepcję tekstu naszej I MEP, jednocześnie zagłębiając nas w jej specyficzny charakter. Elementy składowe każdej modlitwy eucharystycznej tworzą kolejny wachlarz czynników, które nam pomogą wniknąć głębiej $\mathrm{w}$ rozumienie misterium I MEP.

${ }^{65}$ P. M. Gy, La mystagogie dans la liturgie ancienne et dans la pensée liturgique d'aujourd'hui, art. cyt., s. 142-143; D. Sartore, Mistagogia ieri e oggi: alcune pubblicazioni recenti, art. cyt., s. 182-183.

${ }^{66} \mathrm{E}$. Mazza, La mistagogia. Le catechesi liturgiche della fine del quarto secolo e il loro metodo, Roma 1996, s. 11. 


\subsubsection{Dziękczynienie i aklamacja}

Dialog poprzedzający prefację wprowadza nas w akcję dziękczynienia za wspaniałe dzieło pojednania dokonanego przez Boga w swoim ludzie. Dialog ten nie jest adresowany ani do Boga, ani do Chrystusa; chodzi o wymianę pozdrowień pomiędzy kapłanem celebrującym Eucharystię i zgromadzonym ludem.

Kapłan zaprasza zgromadzenie wiernych słowami: „Pan z wami”. Podczas wypowiadania tych słów celebrans główny wyciąga ręce, aby objąć całe zgromadzenie liturgiczne. Rozpoznaje on obecność Chrystusa, który zwołał uczestników, swój lud święty. Dla Chrystusa jesteśmy już pojednani, zgromadzeni we wspólnocie uwielbienia, aby wyśpiewać Jego chwałę. Przez swą odpowiedź: "I $z$ duchem twoim”, lud Boży życzy tej samej obecności Pana temu, który przewodniczy w Jego imieniu zgromadzeniu eucharystycznemu. W rzeczywistości, główny celebrans i wierni składają przez te słowa akt wiary w Boga, obecnego zarówno w osobie wyświęconego kapłana, jak i w zgromadzeniu eklezjalnym ${ }^{67}$.

Kapłan kontynuuje: „W górę serca” i unosi swoje ręce w geście zaproszenia do pozostawienia trosk tego świata, abyśmy zwrócili jedynie uwagę na dzieło, którego Bóg chce dokonać pośród swego ludu. Przejście na pierwszą osobę liczby mnogiej, dokonane przez głównego celebransa, podkreśla że on sam jest częścią zgromadzenia liturgicznego, w imieniu którego za chwilę wyśpiewa Bogu uwielbienie. Zgromadzona wspólnota, przez odpowiedź: „Wznosimy je do Pana”, potwierdza swą gotowość odrzucenia tego, co ziemskie, aby pełniej zagłębić się w dziełach Boga. Taka postawa charakteryzuje dobrze lud, który przez dzieło pojednania odnalazł swego Stworzyciela i teraz chce za Nim podążać. Takie ukierunkowanie człowieka na Boga, do którego kapłan zachęca celebrujące zgromadzenie na początku liturgii eucharystycznej, w tradycji Kościoła wschodniego dało nazwę całej modlitwie eucharystycznej: nosi ona nazwę anafory, co znaczy „ofiarować, podnosząc do góry”68.

W trzeciej strofie dialogu kapłan przez słowa: „Dzięki składajmy Panu Bogu naszemu”, z rękami rozłożonymi, ogarnia wspólnotę, przedstawiając cały program dziękczynienia w tekście, który za chwilę nastąpi i już teraz rozpoczyna „czynić Eucharystię”, obejmując naszą egzystencję, aby ją zanieść przed tron Boży w akcie dziękczynienia. Dzięki składamy za obecność Jezusa Chrystusa, naszego Zbawiciela, pośród nas. Wysłuchaliśmy Jego słowa i teraz chcemy, odpowiadając na nie, celebrować Jego dziękczynienie, które po raz pierwszy

${ }^{67}$ Pius XII, Encyklika Mediator Dei, DC 45, 1948, kol. 200-201; por. Sobór Watykański II, Konstytucja Sacrosanctum Concilium, 7.

${ }^{68}$ Anaphore, DEL, t. 2, s. 509; R. Le Gall, La messe au fil de ses rites, dz. cyt., s. 139. 
złożył w Wieczerniku. Nasza odpowiedź: „Godne to i sprawiedliwe”, potwierdza naszą postawę wobec Boga. Tłumaczenie francuskie osłabia w pewnym sensie łacińską formułę oryginalną i tłumaczy ten tekst poprzez: „Sprawiedliwe to i dobre”. Dziękczynienie jest akcją godną Boga, ponieważ to On sam uczynił nas zdolnymi do tego aktu i powierzył misję jego wypełniania. Jest ono również „sprawiedliwe”, ponieważ może dopełnić obowiązku postawionego nam przez Boga w momencie stworzenia nas jako swoich dzieci umiłowanych ${ }^{69}$.

W całym tym dialogu modlitwa ludu chrześcijańskiego jest rozbudzana i koncentrowana na dziękczynieniu wobec Boga. Każdy z sześciu elementów dialogu opiera się na poprzednim i doprowadza do następnego, tworząc w ten sposób silną dynamikę wstępującą. Kapłan ogłasza obecność Boga w pośrodku swego ludu. Zgromadzenie liturgiczne rozpoznaje obecność Jego Ducha w tym, który przewodzi. Celebrans orientuje akt naszej modlitwy, a wspólnota, wznosząc swój wzrok, wymienia jej adresata. Gesty kapłana harmonizują dobrze ze słowami i sytuacją liturgiczną zaproponowanej modlitwy. Wstęp do aktu dziękczynienia stanowi więc mocny akord w dynamice prefacji ${ }^{70}$.

Pojednana wspólnota rozpoczyna akt dziękczynienia stereotypowym wprowadzeniem: „Zaprawdę, godne to jest, abyśmy Tobie składali dziękczynienie”, aczkolwiek jest ono bardziej wypracowane niż zazwyczaj. Początek w formie bezosobowej nie może nas mylić, to właśnie „my” składamy dzięki Bogu świętemu, pełnemu czułości, miłosierdzia i dobroci. W ten sposób rozpoczynamy realizację programu uwielbienia za dzieło uprzednio zapowiedziane. I MEP już we wstępie do prefacji przedstawia motywy, dla których powinniśmy wyrażać naszą wdzięczność. Wiemy dobrze, iż Bóg pragnie naszego dobra, gdyż „nie przestaje nas powoływać do lepszego i piękniejszego życia” (tłum. pl.: „Ty nieustannie wzywasz grzeszników do odnowy w Twoim Duchu"). Bóg jest wierny i nieustannie nam ofiaruje swoje przebaczenie, gdyż wie, że jesteśmy słabi i grzeszni. Dlatego też deklaruje nam Swoją pomoc i proponuje przywrócić nas „do stanu prawdziwej dobroci”. Pewni prawdziwości tego oświadczenia, możemy sprawować pamiątkę mirabilia Dei dokonanych w przeszłości, a które stanowią przedmiot aktu dziękczynienia, w całym tego słowa znaczeniu, naszej I MEP.

Rozwinięcie aktu dziękczynienia w prefacji zwyczajowo wymienia pewien aspekt dzieł Bożych, których stajemy się uczestnikami poprzez sprawowanie Eucharystii. W I MEP przypominamy przymierze zawierane przez Boga

${ }^{69}$ Cérémonial des évêques, 154 , dz. cyt., s. 50; P. De Clerck, La tradition en acte. La prière eucharistique, LMD 178 (1989), s. 83-86; O. de Cagny, Les prières eucharistiques, Paris 2003, s. 38-42.

${ }^{70}$ A. Catella, La Preghiera eucaristica, „Rivista di Pastorale Liturgica” 38 (2000), nr 219, s. 32-33; P. De Clerck, L'intelligence de la liturgie, Paris 2005, s. 176-180; Zrozumieć liturgię, tłum. I wyd. S. Czerwik, Kielce 1997, s. 168-172. 
z ludzkością. Nasza modlitwa otrzymuje specjalną motywację dzięki wierności Bożej, który nie rezygnuje z człowieka, mimo że ludzkość niejednokrotnie łamie Jego przymierze. Wprost przeciwnie, Bóg daje ludzkości jeszcze jedną szansę dzięki przymierzu zawartemu przez Swego Syna, a naszego Odkupiciela. To przymierze jest ostateczne i nikt nie jest w stanie go złamać. Nasze dziękczynienie znajduje więc bardziej solidny fundament i powinno być bardziej stałe.

To bowiem teraz nadszedł dla nas „czas pojednania i pokoju”. W czasie powstawania modlitw eucharystycznych o tajemnicy pojednania, ten czas specjalny dotyczył Roku Świętego 1975. Dla nas natomiast, nasza obecność na Eucharystii daje możliwość „odzyskania oddechu” w świecie, który „pędzi nieustannie do swojej zguby". Msza święta stanowi czas uprzywilejowany, podczas którego możemy w sposób specjalny spotkać się z Bogiem. Wzmocnieni Jego łaskami, dzięki mocy Ducha Świętego, możemy stać się bardziej aktywni w służbie miłości wobec braci. Emboliom prefacji pobudza nas do zmiany stylu naszego życia i ukierunkowanie go na dobro całej ludzkości. W rzeczywistości, ten który czuje się zbawiony, obiekt miłości i upodobania Zbawiciela, poczuwa się bardziej do odpowiedzialności i przyłączy się łatwiej do misji powierzonej mu przez Boga. Wydaje się oczywistym fakt, iż dziękczynienie jest nie tylko słowem lecz „aktem”, dlatego też jest jasne, że cały Kościół powinien czuć się pociągnięty doświadczeniem dziękczynienia w czynie ${ }^{71}$. Uczestnicząc w nowym Przymierzu, napełnieni darami Ducha Świętego, staliśmy się „nowym ciastem, jako że przaśni jesteśmy” (1 Kor 5, 7), aby czynić świat bardziej braterskim.

Nasza modlitwa dziękczynienia jest kontynuowana, chociaż tekst prefacji prawie się kończy. Na nowo wprowadzenie do Sanctus, stereotypowe w innych modlitwach eucharystycznych, jest dość rozbudowane w I MEP. Jesteśmy „pełni podziwu i radości z odnalezionego zbawienia” dokonanego przez Boga w Chrystusie. Kościół znajduje się w ten sposób w punkcie centralnym, $\mathrm{w}$ momencie najbardziej uroczystym sprawowanej liturgii, nie tylko jako interlokutor Boga Zbawiciela z przeszłości, ale we wspólnocie mężczyzn i kobiet odkrywających na własne oczy wielkie dzieła Boże w nunc historii zbawienia. W takich to okolicznościach, wraz „Z niezliczonymi chórami Aniołów i Świętych", jednoczymy nasz głos, aby wyśpiewywać potęgę i miłość Bożą.

Aklamacja Sanctus włącza głos zgromadzonych na liturgii w ten, który nieustannie rozbrzmiewa $\mathrm{w}$ chórach anielskich, by wspólnie wyśpiewać świętość Najwyższego. To On, „Pan zastępów”, jest Tym, który w tym momencie

${ }^{71}$ G. Cavagnoli, La preghiera eucaristica, modello di preghiera cristiana, „Rivista di Pastorale Liturgica" 37 (1999), nr 214, s. 10; P. M. Gy, L'Eucharistie dans la tradition de la prière et de la doctrine, LMD 137 (1979), s. 86-87. 
łączy niebo z ziemią, stworzenia ziemskie i niebieskie w jednym uwielbieniu, wyśpiewywanym z wdzięczności przez lud Boży. Bóg jest obecny ze swej łaskawości niewyczerpanej nie tylko w niebie, gdzie według języka biblijnego mieszka chwała Boża, ale czyni ze swej chwały skuteczny dowód swojej obecności w świecie i historii ludzkości. Radosny śpiew Hosanna ogłasza realność zbawienia, zakomunikowaną przez świętość i chwałę Bożą wspomnianą powyżej.

W drugiej części Sanctus przyjmujemy wraz z błogosławieństwem Tego, który przyszedł nas zbawić $\mathrm{z}$ woli Ojca. Podobnie jak tłumy w dniu Jego uroczystego wjazdu do Jerozolimy, wykrzykujemy nasze Hosanna, tym razem Jezusowi jako naszemu Odkupicielowi. Jeśli potrafilibyśmy przynajmniej w niewielkim stopniu wejść w dynamikę duchową prefacji, śpiew Święty, święty, który jest jej ukoronowaniem, powinien wstrząsnąć sklepieniami gotyckimi i sufitami betonowymi naszych kościołów. Skoro tak się niestety nie dzieje, służy on jedynie jako pasaż do epiklezy konsekracyjnej i uświęcających słów Chrystusa wypowiadanych przez kapłana nad darami ofiarnymi, przyniesionymi wcześniej przez przedstawicieli zgromadzenia liturgicznego ${ }^{72}$.

\subsubsection{Uświęcenie i aklamacja}

Po wyśpiewaniu uroczystego Benedictus, adresowanego do Chrystusa, nasza modlitwa na nowo kieruje się do Boga. Podejmujemy śpiew uroczystego Sanctus, aby zaakcentować jeszcze raz świętość Boga Ojca. Świętość ta nie jest kontemplowana sama $\mathrm{w}$ sobie, ale jest komunikowana $\mathrm{i}$ jaśnieje $\mathrm{w}$ ofierze Chrystusa, a przez Eucharystię staje się obecna w naszej rzeczywistości. Bóg Ojciec „czyni nas uczestnikami Swego zamysłu miłości” i chce, „abyśmy byli świętymi, jak On sam jest święty" (PSc, I MEP). Nasze uświęcenie dokonuje się dzięki Eucharystii, a w sposób szczególny w przyjęciu Ciała i Krwi Chrystusa. Dary ofiarne, złożone na ołtarzu, w tym momencie nie są jeszcze konsekrowane, Post-Sanctus pomaga nam przejść od adoracji Boga, który jest święty do komunikacji „świętości sakramentalnej” w celebracji eucharystycznej. Dokonanie tego przejścia zostało powierzone Duchowi Świętemu, który został dany przez Chrystusa swojemu Kościołowi. Epikleza konsekracyjna, która w tym momencie następuje, prosi Boga o Jego interwencję w konsekracji darów ofiarnych, które zostaną przemienione w Ciało i Krew Chrystusa naszego Zbawiciela.

${ }^{72}$ R. Le Gall, La messe au fil de ses rites, dz. cyt., s. 144-146; A. Join-Lambert, Guide pour comprendre la messe, dz. cyt., s. 103-104. 
Znajdujemy się w centrum akcji liturgicznej, epikleza konsekracyjna podkreśla w sposób jak najbardziej wyraźny tę tajemniczą i niewypowiedzianą obecność Ducha Świętego. To On stanowi początek komunii i jedności animującej zgromadzoną wspólnotę, a także źródło wszelkich modlitw błagalnych następujących po sobie podczas całej celebracji eucharystycznej. Tak jak życiu chrześcijańskiemu towarzyszy moc pochodząca z góry, podobnie akcja sakramentalna jest wypełniana mocą Ducha, aby stać się darem sakramentalnym, pochodzącym od Ojca. Epikleza oznacza i wyraża na sposób widoczny dzieło stwarzania, jednoczącą i uświęcającą działalność Ducha Pana w Jego Kościele ${ }^{73}$. Moment epikletyczny każdej modlitwy eucharystycznej jest przygotowywany stopniowo podczas celebracji eucharystycznej i to właśnie teraz postacie konsekrowane stają się dla nas pokarmem $\mathrm{w}$ drodze do Boga Ojca. Epikleza konsekracyjna podkreśla jeszcze raz naszą jedność i dziecięctwo Boże, które zostało w nas odnowione dzięki misji zbawczej, podjętej dla nas przez Jezusa Chrystusa. Ręce kapłana w geście epikletycznym wyciągnięte nad złożonymi darami i znak krzyża uczyniony nad nimi stanowi pierwszą część konsekracji ${ }^{74}$.

Wola Boga Ojca, zbawiającego swój lud, wypełniła się w momencie naszej niezdolności zbliżenia się do Niego. W Swym wielkim miłosierdziu interweniuje, by wyrwać nas z drogi zatracenia. Posyła nam własnego Syna, aby nas pojednać ze Sobą. Jedyny Sprawiedliwy pozwala przybić się do krzyża, aby dać jeszcze jedną szansę naszemu życiu.

Nowy początek jest możliwy dzięki pokarmowi niebieskiemu, który otrzymujemy przy stole Chrystusa. On sam dał nam udział w swej uczcie eucharystycznej, gdy po raz pierwszy sprawował ją w Wieczerniku. Zanim oddał życie dla naszego zbawienia, zgromadził swoich uczniów, aby podzielić się z nimi chlebem i winem. Pozostawił nam Eucharystię, jako pamiątkę swego dzieła zbawczego, przypieczętowanego na krzyżu i ratyfikowanego zmartwychwstaniem, która staje się niezatartym znakiem nowego Przymierza. Świadomość celebracji tej samej akcji liturgicznej, kiedyś dokonanej przez samego Mistrza, ożywia naszą modlitwę.

Jezus nas prosił: „To czyńcie na moją pamiątkę” (Łk 22, 19). Aktualizując „recytatyw założyciela" akcji liturgicznej, troszczymy się o sprawowanie „Wieczerzy Pańskiej” (1 Kor 11, 20-21). Wspólnota eucharystyczna ostatecznie

${ }^{73}$ A. Donghi, Dall'epiclesi liturgica alla vita secondo lo Spirito, „Rivista di Pastorale Liturgica” 30 (1992), nr 173, s. 42.

${ }^{74}$ Gesty liturgiczne, dz. cyt., s. 19; C. Cibien, Comunicazione non verbale nella Preghiera eucaristica, „Rivista Liturgica” 83 (1996), s. 729-730. 
skupia się na akcji samego Chrystusa. „My” celebrującej wspólnoty staje się „On” w ustach głównego celebransa, ażeby w końcu stać się „Ja” samego Chrystusa w słowach konsekracji ${ }^{75}$.

Akcja liturgiczna uobecnia chrześcijanom, w istocie rzeczy, nie Wieczernik Chrystusa, ale jego rzeczywistość: życie wieczne przekazane przez Jezusa swoim uczniom w momencie śmierci na krzyżu. W Ciele i Krwi Chrystusa, ofiarowanych na ołtarzu, streszcza się dar Jego całej egzystencji, Jego niezniszczalnej wierności. I MEP przypomina nam to wydarzenie w słowach wprowadzających do formuły konsekracyjnej nad kielichem. Obecnie mamy udział w Kielichu Chrystusa, ponieważ nas pojednał „przez krew wylaną na krzyżu”76.

Gesty towarzyszące recytatywowi ustanowienia pomagają nam zagłębić się $\mathrm{w}$ misterium obecności Zbawiciela wśród nas. Chociaż pochodzą ze średniowiecza, wyrażają dobrze zgromadzenie Kościoła, lud Boży, pod przewodnictwem Jezusa, który jest głową zgromadzonego ludu (Kol 1, 18). Podniesienie hostii i wina konsekrowanego, jak również postawa klęcząca lub głęboki ukłon zgromadzonych (OWMR 43) tworzą moment adoracji i są odczuwane jako szczyt tej części Eucharystii, która kończy akcję uświęcającą dary ofiarne ${ }^{77}$.

Bezpośrednio po konsekracji znajdujemy potwierdzenie tegoż punktu kulminacyjnego w słowach śpiewanej lub recytowanej przez kapłana aklamacji: "Oto wielka tajemnica wiary". Aklamacja ta pojawiła się w nowych modlitwach eucharystycznych i dobrze spełnia rolę przejścia od słów ustanowienia do anamnezy, dając wrażenie doskonałej kontynuacji modlitewnej ${ }^{78}$. Aklamacja anamnetyczna, dając możliwość uczestnictwa zgromadzeniu eucharystycznemu w modlitwie kapłana, wyraża przede wszystkim naszą wdzięczność za wielkie dzieła dokonane przez Jezusa Chrystusa. Adresowana jest do Chrystusa obecnego wśród nas. To swego rodzaju „wyznanie wiary” w trzy akcje zbawcze dokonane przez Jezusa, aby nas zbawić i dać nadzieję na życie wieczne ${ }^{79}$.

${ }^{75}$ P. De Clerck, La tradition en acte. La prière eucharistique, art. cyt., s. 87-88; F. Gomiero, Il canto nella Liturgia Eucaristica: Parte seconda: Quando e che cosa cantare?, „Rivista di Pastorale Liturgica” 34 (1996), nr 195, s. 55-56.

${ }^{76}$ G. Cavagnoli, La preghiera eucaristica: schemi di catechesi, „Rivista di Pastorale Liturgica” 39 (2001), nr 228, s. 57; P. De Clerck, Réflexions théologique, LMD 203 (1995), s. 161-162.

${ }^{77}$ P. De Clerck, La célébration eucharistique. Son sens et sa dynamique, w: Eucharistia. Encyclopédie de l'Eucharistie, dz. cyt., s. 339.

${ }^{78}$ Święta Kongregacja Rytów, Acclamationes post consecrationem, ad libitum seligendae, „Notitiae” 4 (1968), s. 179; A. Vinel, Lacclamation après la consécration: Note sur le chant d'anamnèse, „Notes de Pastorale liturgique" 75 (1968), s. 37-38.

${ }^{79}$ M. Veuthey, La preghiera eucaristica, „Rivista Liturgica” 86 (1999), s. 311-312; Aby prześledzić pojawienie się i inne propozycje aklamacji w modlitwie eucharystycznej rzymskiej czy też $w$ innych modlitwach eucharystycznych zob. H. Goltzen, Acclamatio anamneseos. Die Gemeinde-Anamnese 
Przywołanie Chrystusowej śmierci, zmartwychwstania i przyjścia w chwale uświadamia nam, że jesteśmy w trakcie celebracji całego misterium paschalnego naszego odkupienia. Aklamacja ta jest jakby syntezą podstawowych racji, dla których zgromadził się lud wierny. Zanim przypomnimy je sobie w anamnezie, adresowanej do Boga Ojca, wnikamy w modlitwę Chrystusa, uczestnicząc aktywnie w Jego ofierze ${ }^{80}$.

Zmiana adresata naszej modlitwy z Chrystusa na Boga Ojca stanowi dynamizm modlitwy eucharystycznej, pozwalający nam wejść w prośby zwrócone do Boga, mając Chrystusa jako Orędownika i jedynego Pośrednika pomiędzy Bogiem i ludźmi.

\subsubsection{Prośby i aklamacja}

Misterium Paschy przemienia się $\mathrm{w}$ rzeczywistość sakramentalną, dary ofiarne są przeobrażone. Pamiątka tych wydarzeń nie jest ucieczką w przeszłość, ale rozpoznaniem Jego obecności w nunc Kościoła. Wspólnota celebrująca, „obchodząc pamiątkę śmierci i zmartwychwstania" Chrystusa, przedstawia Bogu „Ofiarę, która całej ludzkości daje pojednanie” i prosi Boga, aby ją łaskawie przyjął. Jesteśmy zabezpieczeni obecnością Chrystusa, „naszej Paschy i ostatecznego pokoju", który jest pewnym pasażem do Ojca. Oczekujemy jedynie „błogosławionego dnia Jego przyjścia na końcu czasów”, który będzie naszą ostateczną radością.

To przywołanie eschatologiczne, czyniąc pamiątkę ostatecznego przyjścia Zmartwychwstałego, przygotowuje nas, czy też przez celebrację Eucharystii daje nam przedsmak przyszłości wiecznej. W każdym bądź razie wiemy, w kim złożyliśmy naszą ufność i do kogo kierujemy naszą prośbę: do „Boga prawdziwego i wiernego". Prawdziwe uczestnictwo w Eucharystii, realizowane przez modlitwę rytualną, przejawia się w dyspozycyjności wspólnotowej do stawania się "Ciałem wydanym” i "Krwią przelaną" Chrystusa, czyniąc w ten sposób jeszcze bardziej żywą pamiątkę Chrystusa w historii ${ }^{81}$. Te treści składają się na następną prośbę, którą jest epikleza komunijna.

des eucharistischen Hochgebetes, „Jahrbuch für Liturgik und Hymnologie” 19 (1975), s. 187-195; M. Schneiders, Acclamations in the eucharistic prayer, w: Omnes circumadstantes: Contributions towards a history of the role of the people in the liturgy, Ch. Caspers, M. Schneiders (red.), Kampen 1990, s. 78-100; A. Gerhards, Akklamationen im Eucharistiegebet. Funktion und Gestalt im Liturgievergleich, w: Crossroad of Cultures, H. J. Feulner, E. Velkovska, R. Taft (red.), Roma 2000, s. 315-329.

${ }^{80} \mathrm{~J}$. Gelineau, Lacclamation d'anamnèse, „Assemblées du Seigneur”, $2^{\mathrm{e}}$ série, Paris 1968, $\mathrm{nr} 2$, s. 17-19; dla innych aklamacji języka francuskiego zob. D. Dufrasne, L’anamnèse de la Cène dans les anaphores orientales, „Communautés et Liturgies” 66 (1984), s. 227-229.

${ }^{81}$ G. Cavagnoli, L'ultima Cena di Gesù e il racconto ecclesiale in rendimento di grazie, „Rivista Liturgica" 88 (2001), s. 347-351. 
Przedmiotem tej epiklezy jest prośba do Ducha Świętego, aby obdarzył wszystkich, którzy przystąpią do Komunii świętej w jedynej ofierze Chrystusa, darem świętości, by stali się $\mathrm{z}$ nią jednością. W tej prośbie I MEP przywołuje jeszcze raz nieskończoną miłość Ojca dla tych, którzy przyszli go uwielbiać. Potrafimy dopełnić naszego dziękczynienia, ponieważ Bóg w swojej dobroci daje nam możliwość komunii w „jedynej Ofierze Jezusa Chrystusa. Przez moc Ducha Świętego", Bóg nam pozwala stać się Ciałem Jezusa zmartwychwstałego. Upraszając u Boga dar jedności, dokonany w Duchu Świętym, jesteśmy zanurzeni w misterium paschalnym Chrystusa, „który znosi wszelkie podziały”. Ta łaska jedności charakteryzuje lud pojednany z Bogiem i braćmi. W naszej modlitwie nie chcemy ograniczyć się jedynie do zgromadzonej wspólnoty, toteż w następnej prośbie ogarniamy całą wspólnotę Kościoła.

Prośba wzajemnej komunii ducha i serca we wspólnocie kościelnej wysuwa się na pierwszy plan. Prośba przypomina naszą więź z Kościołem ziemskim przez modlitwę w intencji Ojca świętego i Kościół lokalny reprezentowany przez biskupa diecezjalnego. Wspólnie, w jedności, usiłujemy przygotować przyjście Królestwa niebieskiego. Nasza modlitwa będzie trwała aż do momentu spotkania we wspólnocie ostatecznie pojednanych, którzy cieszyć się będą chwałą niebieską, zarezerwowaną świętym w królestwie naszego Ojca. Wraz z nimi znajdziemy się w obecności Boga, abyśmy mogli kontemplować Jego chwałę i miłosierdzie, zarezerwowane każdemu grzesznikowi.

Nasza prośba podkreśla fakt, iż Eucharystia jest celebrowana w łączności z całym Kościołem powszechnym, tym w niebie i na ziemi, oraz że ofiara Chrystusa została złożona za cały Kościół wraz ze swymi członkami żywymi i tymi, którzy już odeszli do Pana (OWMR 79g). Ta nadzieja urzeczywistniana motywuje nieustannie nasze dziękczynienie eucharystyczne, dając nam możliwość poznania całej prawdy. Jeżeli czasy doczesne naznaczone są zepsuciem, jak świadczą o tym prośby, działalność Boga w mocy Ducha Świętego orientuje nas w kierunku nowej ery, gdzie odnajdziemy się „w sercu nowego stworzenia”. W tej perspektywie rozumiemy lepiej wspomnienie świętych oraz wiernych zmarłych. To dopiero w tym momencie, u boku Najświętszej Dziewicy Maryi i Apostołów, „z naszymi zmarłymi braćmi i siostrami”, będziemy mogli śpiewać, jako ludzie prawdziwie pojednani, „hymn dziękczynienia (...) Chrystusa żyjącego na wieki"82. W wezwaniach dobitniej wybrzmiewa pogłębione "my” ludu Bożego, podmiot charakteru dziękczynnego Eucharystii, który zbiega się $\mathrm{z}$ całą spontanicznością w wielkiej doksologii.

${ }^{82}$ G. Cavagnoli, La preghiera eucaristica: schemi di catechesi, art. cyt., s. 64-65. 
Modlitwa nasza przechodzi dość naturalnie w kierunku tej ostatniej części I MEP. Słowa adresowane do Boga Ojca głoszą realizację programu zapowiedzianego $\mathrm{w}$ dialogu rozpoczynającym prefację. W tych bardzo prostych słowach odnajdujemy zarazem wielką kondensację modlitwy i minitraktat teologii trynitarnej. Jest tu podkreślona cała orientacja życia chrześcijańskiego na komunię z Bogiem. Ażeby wszystko w nas stało się uwielbieniem Boga, w którym możemy odnaleźć pojednanie i ostateczny pokój, nie mamy innej drogi jak ta, którą ukazuje nam Chrystus w mocy Ducha Świętego, który jest pieczęcią jedności ${ }^{83}$.

Gest podniesienia darów ofiarnych, towarzyszący doksologii, przedstawia Bogu dary uświęcone wraz ze śpiewem czci i chwały. Aklamacja Amen, kończąca doksologię, dopełnia wszelkiego dziękczynienia w wielkiej modlitwie eucharystycznej. Zwyczajowo ta aklamacja powinna być podkreślona śpiewem, ponieważ jest najważniejszym Amen w całej celebracji eucharystycznej ${ }^{84}$.

Modlitwa wdzięczności jest kontynuowana przez Kościół Chrystusowy za wielkie dzieło naszego pojednania. Nowe stworzenie, w którym mamy swój udział, korzysta teraz z czasu łaski i pojednania w każdym eucharystycznym spotkaniu. Lud nowego Przymierza, w którym zostały pokonane wszelkie przeszkody i podziały, uświęca swoje życie i próbuje zmienić egzystencję ludzkości.

\subsection{Pogłębienie mistagogiczne II MEP}

II MEP wyraża językiem codziennym wielkie misterium naszego odnalezienia się przed Bogiem na łonie ludu Bożego. Odkupieńcze dzieło Chrystusa pozwala odmienić tragiczną sytuacjęludzi oddalonych od Boga. Dzięki temu człowiek odnajduje pokój i komunię we wspólnocie Kościoła. Dlatego też, wspólnota eucharystyczna potrzebuje wyrażenia swojej wdzięczności Bogu za dzieła miłości dokonane w naszym świecie.

\subsubsection{Dziękczynienie i aklamacja}

Tradycyjny wstępny dialog pomiędzy kapłanem i zgromadzeniem eucharystycznym wprowadza nas w akcję dziękczynienia wyrażoną w prefacji II MEP. W naszej modlitwie wychodzimy od doświadczenia ziemskiego, wyrażając naszą wdzięczność za dzieło pojednania. Nasze dziękczynienie i uwielbienie

\footnotetext{
${ }^{83}$ A. Join-Lambert, Guide pour comprendre la messe, dz. cyt., s. 110.

${ }^{84}$ Kongregacja Sakramentów i Kultu Bożego, Instrukcja Inaestimabile donum w sprawie niektórych norm dotyczących kultu tajemnicy eucharystycznej, 4.
} 
otrzymują natychmiast pośrednika przed Ojcem, Jezusa Chrystusa, naszego Pana i Zbawiciela, który przedstawiając nasze modlitwy, dziękuje Bogu Ojcu za „przedziwne dzieło odkupienia” dokonane na tej ziemi.

Nasza wdzięczność jest tym większa, iż Bóg nie przestaje działać, nawet wtedy gdy ludzkość jest „poróżniona i rozdarta”. To On jest pierwszym źródłem pokoju, który chciałby zobaczyć nas żyjących w pokoju (J 14, 27; 1 Kor 7, 15; Ef 2, 14-15). Wiemy o tym, dlatego też teraz, w centrum naszej celebracji eucharystycznej, chcielibyśmy uroczyście ogłosić, że Bóg jest „u źródeł wszelkiego wysiłku ludzkości do pokoju”: „Bo królestwo Boże to nie sprawa tego, co się je i pije, ale to sprawiedliwość, pokój i radość w Duchu Świętym" (Rz 14, 17).

Działanie Ducha Świętego podczas Eucharystii pozwala rzeczywiście na odnalezienie równowagi „w głębinach serca” ludzkiego, którą niełatwo zachować w świecie nas otaczającym. Duch Święty poprzez język liturgiczny kształtuje i buduje w zgromadzeniu eucharystycznym autentyczne postawy chrześcijańskie. Inspiruje wiarę, nadzieję i miłość wśród zgromadzonych i pobudza ich do śpiewu radości i uwielbienia Boga za dzieło stworzenia ${ }^{85}$. To działanie nie ogranicza się jedynie do akcji liturgicznej, ale można je poszerzyć na całe życie wiernych.

W II MEP wyrażamy naszą wdzięczność Bogu za dzieła Jego Ducha dokonujące się w naszym życiu codziennym. Nieprzyjaciele, którzy spotykając się nie pozdrawiali się nawet, dzięki działaniu Ducha na nowo ze sobą rozmawiają. Dwaj piłkarze należący do przeciwnych drużyn, za natchnieniem Ducha, po kłótni podają sobie rękę. Relacje dyplomatyczne, zerwane pomiędzy krajami stojącymi w opozycji, dzięki Duchowi Świętemu są na nowo nawiązane. Narody usiłujące na różnych płaszczyznach wzajemnie się zrozumieć „godzą się przejść wspólnie część drogi”86.

Kontynuujemy naszą modlitwę, uznając wielkość dzieł Bożych w naszym ludzkim świecie. Cały czas ukazuje się działalność Boża, dokonana w mocy Ducha Świętego, gdy:

- „szczere szukanie pokoju gasi spory”;

- „miłość zwycięża nienawiść”;

- „pragnienie zemsty ustaje przez przebaczenie”.

W obliczu doniosłości i życzliwości działania Bożego wobec człowieka, czujemy się zobowiązani do błogosławienia i dziękczynienia wobec Niego. W każdym bądź razie, należy podkreślić, że nie jest to naszym obowiązkiem,

${ }^{85}$ A. Donghi, Dall'.epiclesi liturgica alla vita secondo lo Spirito, art. cyt., s. 43-44.

${ }^{86}$ Zwroty użyte przez H. Rennings, Votivhochgebet Versöhnung II, w: Gratias agamus. Studien zum eucharistischen Hochgebet für Balthasar Fischer, A. Heinz, H. Rennings (red.), Freiburg - Basel - Wien 1992, s. 413. 
ale czynimy to $\mathrm{z}$ potrzeby serca. To dlatego $\mathrm{w}$ naszej modlitwie, $\mathrm{w}$ momencie w którym się znajdujemy, chcemy połączyć nasze głosy z tymi,którzy wyśpiewują uwielbienie Boga w niebiosach. Rozgłaszamy jednogłośnie z chórami niebieskimi świętość Boga w pieśni uwielbienia.

Sanctus w modlitwach eucharystycznych jest przede wszystkim ukoronowaniem prefacji, tutaj jest bardziej „zawiasem” pomiędzy dwiema storami dziękczynienia. Pierwsza część hymnu Święty, święty... przypomina nam, że adresatem naszej modlitwy jest „Pan Bóg Zastępów”, Bóg po trzykroć święty, wypełniający Swoją chwałą całe niebo i ziemię. Przez to przypomnienie wynosimy pod niebiosa dzieła potęgi Bożej w misterium Chrystusa i upraszamy wypełnienia tego dzieła na łonie Kościoła w czasie trwania akcji eucharystycznej ${ }^{87}$. Druga część Sanctus przygotowuje właśnie dziękczynienie za dzieła dokonane przez Chrystusa przychodzącego „w imię Pańskie” dla naszego zbawienia.

Tekst II MEP, następujący po Sanctus, uwielbia „Boga wszechmogącego” za dar Syna, Jezusa Chrystusa. Składamy dzięki za przyjście Jezusa na ziemię. Przybył On w imię swego Ojca, aby nas zbawić i odnowić w nas dziecięctwo Boże. W naszej modlitwie to Jemu przypisujemy teraz trzy zwroty zawarte $\mathrm{w}$ prefacji. Jesteśmy pełni wdzięczności za dzieło pojednania dokonane w Jezusie, który staje się „Słowem” Boga zbawiającym nas (2 Kor 5, 18-19). W Nim Bóg „wyciąga rękę do grzeszników”, aby człowiek mógł stać się dziedzicem pokoju Bożego. To Jezus jeszcze raz jest nazwany „Drogą, która nasz prowadzi do prawdziwego pokoju”.

Powinniśmy tym bardziej wyrazić naszą wdzięczność Bogu, gdyż posłał Swego Syna, gdy byliśmy oddaleni od Niego. Dzięki Jego własnemu Synowi, „wydanemu w ręce ludzkie”, Bóg uwolnił nas od naszych słabości. Dzięki Niemu rodzaj ludzki może zasmakować pokoju, pokoju z Bogiem i pokoju z drugim człowiekiem. Cena, którą Bóg musiał zapłacić jest niestety bardzo wielka, to śmierć własnego Syna.

Jak moglibyśmy być niewdzięczni? Celebrujemy teraz „z wdzięcznością, misterium pojednania, które On sam nam wysłużył".

\subsubsection{Uświęcenie i aklamacja}

Wezwanie, cytowane powyżej, należy do epiklezy konsekracyjnej. Przypomina nam ono z kompetencją, że świętowana Eucharystia jest celebracją naszego pojednania w Chrystusie. Wyrażając naszą wdzięczność za otrzymane

${ }^{87}$ A. Houssiau, Les moments de la prière eucharistique, w: L'Expérience de la prière dans les grandes religions, H. Limet, J. Ries (red.), Louvain - la - Neuve 1980, s. 333-334; por. CNPL, L'art de célébrer. Aide-mémoire des animateurs, t. 2, Paris 2003, s. 52. 
łaski, w pełni świadomości naszych ograniczeń, sprawujemy naszą ofiarę jak "Jezus przykazał nam to czynić"

Nasza ofiara jest duchowa, uświęcona Duchem, gdyż wierny jest przepełniony mocą Ducha Świętego, aby śpiewać pieśń uwielbienia Bogu. Właśnie teraz w naszej modlitwie prosimy Ojca, by raczył posłać Swego Ducha dla uświęcenia Jego mocą darów złożonych przez Kościół. To jest bowiem rolą Ducha Świętego, aby wziął udział w konsekracji. Z darów przygotowanych do złożenia ofiary Bóg czyni ciało sakramentalne Chrystusa, które następnie przemieni nas w Ciało Chrystusa, którym jest Kościół w epiklezie post-konsekracyjnej ${ }^{89}$.

Działanie Ducha Świętego łączy naszą modlitwę bezpośrednio z opisem ustanowienia z Wieczernika. Podkreślamy charakter wspólnotowy Ostatniej Wieczerzy, którą Chrystus spożywał ze swymi uczniami oraz jej adresata, Boga Ojca, wspominanego kilkakrotnie w tej części naszej modlitwy. Dziękujemy Chrystusowi za Jego decyzję ofiarowania się Ojcu „dla naszego zbawienia”, a także za chleb, który połamał własnoręcznie, by stać się pokarmem duchowym. Akcja uświęcenia nie jest jeszcze dopełniona, wyrażamy naszą wdzięczność również za „kielich błogosławieństwa”, złączony w naszej modlitwie $\mathrm{z}$ miłosierdziem Bożym, z którego płynie nasze pojednanie. Prośba Chrystusa wypełnienia Jego pamiątki, przekazanej nam na Ostatniej Wieczerzy, kończy akt konsekracji. Uznajemy i potwierdzamy ten fakt śpiewem aklamacji anamnetycznej. „Wielka tajemnica wiary”, celebrowana przez Kościół, ogłasza Chrystusową śmierć i zmartwychwstanie w oczekiwaniu Jego przyjścia w chwale i służy odnalezieniu Jego miłości dzięki ofiarowanemu nam pojednaniu.

Chrześcijanie nieustannie oczekują ostatecznego pojednania, które stanie się naszym udziałem w Królestwie niebieskim. Celebrując liturgię eucharystyczną jesteśmy w stanie nieustannego oczekiwania przyjścia Pana w chwale, według słów św. Pawła: „Ilekroć bowiem spożywacie ten chleb albo pijecie kielich, śmierć Pańską głosicie, aż przyjdzie" (1 Kor 11, 26). Eucharystia ziemska jest sakramentem sprawowanym w Kościele, ponieważ Pan jeszcze nie przyszedł.

Aklamacja anamnetyczna pomaga nam w sposób zasadniczy włączyć pojęcie pamiątki do naszej modlitwy. Opiera się ona na wydarzeniu zbawczym, które już się dokonało: „Chwała Tobie, który umarłeś”. Ale jednocześnie przekazuje urzeczywistnienie teraźniejszości naszego zbawienia, szczególnie podczas Eucharystii: "Chwała Tobie, który żyjesz” oraz przywołuje pełną realizację miłości Bożej w Królestwie niebieskim: „Przyjdź Panie Jezu” (Ap 22, 20)90.

${ }^{88}$ W. J. Grisbrooke, The New Eucharistic Prayers of the Roman Rite. A Guide to Catechesis, „Liturgy” 21 (1998/99), s. 25.

${ }^{89}$ J. F. Puglisi, Quelques exemples de convergence dans les prières eucharistiques, LMD 139 (1979), s. 118-120; CNPL, L'art de célébrer, dz. cyt., s. 55-56.

${ }^{90}$ Por. CNPL, L'art de célébrer, dz. cyt., s. 60. 


\subsubsection{Prośby i aklamacja}

Obchodząc pamiątkę Wieczerzy Pana, możemy postawić sobie pytanie dotyczące realnej obecności ofiary Chrystusa w akcji liturgicznej. Po tym wszystkim, co już zostało na ten temat powiedziane we wcześniejszych rozdziałach pracy, wydaje się być przydatnym zacytowanie jeszcze starego tekstu, zaczerpniętego z superoblaty drugiej niedzieli zwykłej: „Ilekroć bowiem sprawujemy pamiątkę Ofiary Chrystusa, spełnia się dzieło naszego odkupienia" ${ }^{91}$.

Według II MEP nasza celebracja jest pamiątką miłości, którą Jezus pozostawił jako gwarancję wierności w swoim Kościele. Sprawując ją w Eucharystii, przypominamy śmierć i zmartwychwstanie naszego Pana, ale oddajemy również Ojcu tę ofiarę, która w rzeczywistości od Niego pochodzi. Błagamy Ojca, aby wraz $\mathrm{z}$ ofiarą pojednania przyjął również nas i odnowił w Swojej łasce. Nasza prośba wspólna zakłada odnowienie pojednania również pomiędzy braćmi.

Po przedstawieniu Ojcu darów ofiarnych, nasz tekst wyraża się w ten sposób, by uczynić owocną modlitwę anamnezy. Kościół nie może otrzymać, przez pośrednictwo Jezusa, żadnego daru łaski i zbawienia, bez udziału Ducha Świętego, który jest nazwany „autorem wszelkiego uświęcenia”92.

Zazwyczaj, w tej części modlitwy eucharystycznej, prosimy o uświęcenie zgromadzenia liturgicznego przez udział w darach konsekrowanych podczas przyjmowania Komunii świętej. W epiklezie komunijnej II MEP uświęcenie jest specyficznie pojmowane. Prosimy, aby Duch Święty „usunął przyczyny naszych podziałów" i utwierdził nas w komunii z braćmi. Przyjaźń braterska, która powinna naturalnie wypływać z Komunii eucharystycznej, jest specjalnie podkreślona przez II MEP, jako owoc pojednania dokonanego przez zniknięcie jabłka niezgody. Prosimy Ducha Świętego, „aby utwierdzał nas w coraz większej miłości". W tej miłości realizujemy naszą jedność z Ciałem Chrystusa, którym jest Kościół, w osobach papieża i biskupa miejsca, skończywszy na całym ludzie Bożym.

W dalszej części naszej modlitwy, Bóg Ojciec na nowo bezpośrednio jest wzywany jako adresat naszych próśb. Modlimy się za cały Kościół, aby stał się „widocznym znakiem jedności i sługą pokoju”. Nie ma mowy o Kościele - instytucji, ale oczywiście o żywej wspólnocie Kościoła: ten, który służy, na

${ }^{91}$ Mszał rzymski, dz. cyt., s. 243; nie wchodzimy tutaj w dyskusje nad sposobem obecności ofiary Chrystusa w Eucharystii: por. B. Neunheuser, Mystère, w: DEL, t. 2, s. 55-69; niech wystarczy nam wiedzieć, że „celebracja misterium jest tylko ćwiczeniem rytualnym, który uobecnia wydarzenie zbawcze”, wg wyrażenia Salvatore Marsili, cyt. za: E. Lodi, La mystagogie des textes du Missel Romain d'après ses sources, w: Mystagogie, dz. cyt., s. 182.

${ }^{92} \mathrm{~B}$. Bobrinskoy, Comment le Christ et le Saint-Esprit se situent-ils l'un par rapport à l'autre dans la liturgie?, w: Le Christ dans la liturgie, A. Pistoia, A. M. Triacca (red.), Roma 1981, s. 20-33. 
wzór Chrystusa, ma prawo być policzony jako największy w Jego Królestwie (Mt 23, 11; Łk 22, 26-30).

Bóg już teraz otwiera drzwi Swego Królestwa dla zgromadzenia liturgicznego, w którym panuje jedność i pokój. II MEP zapewnia nas w swoich prośbach, że jesteśmy zgromadzeni w komunii modlitewnej wraz z Dziewicą Maryją i wszystkimi Świętymi. Nasza celebracja liturgiczna, „wokół stołu Chrystusa”, jest zapowiedzią uczty wiecznej w Królestwie niebieskim. Nawet, jeśli posiadamy obecnie w Eucharystii przedsmak chwały niebieskiej, to dopiero na wysokościach „będziemy mogli celebrować jedność ostatecznie wypełnioną i pokój ostatecznie zawarty". Uczta Królestwa niebieskiego zgromadzi pewnego dnia „ludzi z każdego kraju i z każdego języka, z każdej rasy i z każdej kultury”, dzięki pojednaniu zrealizowanemu przez Jezusa Chrystusa, naszego Pana.

$\mathrm{W}$ tym momencie radości możemy wyśpiewać dziękczynienie w pełnym tego słowa znaczeniu. Doksologia, w rzeczywistości towarzysząca podniesieniu darów ofiarnych, reasumuje w kilku słowach całą treść modlitwy eucharystycznej. Nasze dziękczynienie kierujemy nieustannie do całej Trójcy Przenajświętszej. Amen wspólnoty eucharystycznej potwierdza i pieczętuje całą modlitwę eucharystyczną.

W świecie współczesnym, gdzie ludzkość jest często „poróżniona i rozdarta”, Bóg w Trójcy jedyny nie zaprzestaje działać. Człowiek nie jest w stanie sam odnaleźć jedności ze swoim Stwórcą; Bóg mu pomaga i posyła Swego Syna, wydanego w ludzkie ręce. Jezus wypełnia Swoją misję pojednania grzesznego człowieka z Bogiem Ojcem. Bóg wyciąga Swoje ręce w kierunku synów marnotrawnych, którzy się odnaleźli i posyła Swego Ducha, aby odnowić prawdziwy pokój. Nasza modlitwa dziękczynienia, sprawowana z wdzięczności za misterium pojednania, ukierunkowuje nas na komunię ostateczną w jedności i pokoju niebieskim. Eucharystia celebrowana jako pamiątka misji pojednawczej naszego Zbawiciela zagłębia nas w misterium pojednania.

Zechciejmy spojrzeć teraz na modlitwę eucharystyczną od strony zgromadzonego Kościoła. Co możemy zaproponować, aby zdynamizować aktywność wspólnoty eucharystycznej w części, która wydaje się całkowicie dotyczyć celebransa głównego. 


\section{Zastosowanie modlitw eucharystycznych w duszpasterstwie Kościoła}

Każde zaangażowanie chrześcijańskie posiada wymiar przekraczający możliwości indywidualne osoby, czy też nawet całej wspólnoty. Uczestniczymy w rzeczywistości misterium Chrystusa na tyle, na ile nasze serce potrafi je przeniknąć. Nasze uczestnictwo w celebracji eucharystycznej jest próbą zrozumienia Tego, którego cały świat nie jest w stanie pomieścić, ale to także przestrzeń rozbrzmiewająca głosami całego stworzenia, która może stać się miejscem pocieszenia i ucieczki dla człowieka ${ }^{93}$. Jak wzmiankuje o tym Ogólne wprowadzenie do Mszału rzymskiego:

„Teraz rozpoczyna się modlitwa eucharystyczna, czyli modlitwa dziękczynienia i uświęcenia, która jest ośrodkiem i szczytem całej celebracji. Kapłan wzywa lud, aby wzniósł serca do Pana, oraz jednoczy go z sobą w modlitwie i dziękczynieniu, jakie w imieniu całej wspólnoty zanosi do Ojca przez Jezusa Chrystusa w Duchu Świętym. Znaczenie tej modlitwy polega na tym, abycałezgromadzenie wiernych zjednoczyło się $\mathrm{z}$ Chrystusem $\mathrm{w}$ głoszeniu wielkich dzieł Bożych i w składaniu Ofiary. Modlitwa eucharystyczna domaga się, aby wszyscy wsłuchiwali się w nią w pełnym czci skupieniu" (OWMR 78).

Modlitwa eucharystyczna zajmuje fizycznie miejsce centralne w akcji liturgicznej. Jest elementem najważniejszym całej celebracji eucharystycznej. Dokumenty Kościoła podkreślają ten wymiar, liturgiści o tym nieustannie mówią, ale jak jest trudno zaakceptować i docenić tę rzeczywistość! Wystarczy orientować się, chociaż trochę w praktyce liturgicznej naszych kościołów, ażeby stwierdzić, że celebrowana modlitwa eucharystyczna jest na nieszczęście jeszcze daleko od podkreślenia doniosłości jej należnej.

W sposób szczególny, od Soboru Watykańskiego II, gdzie udział aktywny wspólnoty wiernych został specjalnie podkreślony ${ }^{94}$, teologowie stawiają sobie

${ }^{93}$ B. Baroffio, La preghiera eucaristica luogo reale di partecipazione attiva dell'assemblea, „Liturgia" 25 (1991), s. 643-644.

${ }^{94}$ Sobór Watykański II, Konstytucja Sacrosanctum Concilium, 14, 19, 21, rozwinięte następnie w artykułach 22 et 40 . Uczestnictwo aktywne całej wspólnoty, ogólnie biorąc, zostało podkreślone w artykułach 26 et 32; aby prześledzić udział wiernych w liturgii do Soboru Watykańskiego II, zob. L. Leijssen, La communauté eucharistique: communauté de personnes en action, „Questions Liturgiques" 64 (1983), s. 125-127; P. Marini, La riforma della preghiera eucaristica dopo il Concilio, „Ecclesia Orans" 16 (1999), s. 163-167; ostatnio cały numer 241 LMD został poświęcony temu tematowi, w sposób szczególny zob. J. Lamberts, L'évolution de la notion de 'participation active' dans le mouvement liturgique du vingtième siècle, LMD 241 (2005), s. 77-120; A. Cuva, La participation des fidèles à la liturgie selon la constitution Sacrosanctum Concilium, LMD 241 (2005), s. 137-149; P. Prétot, Retrouver la 'participation active' une tâche pour aujourd'hui, LMD 241 (2005), s. 151-177. 
tego typu pytania: „Jak celebrować dzisiaj, w szczególny sposób w naszych parafiach, tak aby punkt szczytowy mszy niedzielnej ukazywał wiernym to czym jest ona jest: ofiarą uwielbienia, pamiątką misterium paschalnego i ofiarą duchową Kościoła?"95.

Nie możemy zbyt łatwo liczyć, iż znajdziemy cudowną odpowiedź na to pytanie, problem jest bowiem zbyt złożony. Bardziej fundamentalną wydaje się być kwestia naszej wiary. Jeżeli niektórzy posiadają tyle trudności, aby uchwycić sens tej akcji liturgicznej, może to po prostu znaczyć, że ich wyczucie Eucharystii jest niewystarczające. Sytuacja ta domaga się dogłębnej katechezy, która potrafiłaby naprawdę rozbudzić sens Eucharystii. Następnie można by poruszyć problem języka. Zastanawialiśmy się nad nim przy przedstawianiu zatwierdzania MEP przez Stolicę Apostolską, ale oczywiście trudność dotyczy wszystkich modlitw eucharystycznych, a w szczególności czwartej. I na koniec nie wolno zapominać o funkcjonowaniu samej modlitwy eucharystycznejej.

Modlitwa eucharystyczna, oratio Kościoła, jest sama w sobie actio w pełnym tego słowa znaczeniu. Podczas tej modlitwy actio człowieka ustępuje miejsca actio divina. Kapłan przewodniczący, w imieniu całej wspólnoty, udziela swego głosu Chrystusowi, który tak jak kiedyś w Wieczerniku, dzisiaj, tu i teraz, mówi do nas: „To jest bowiem Ciało mo je” i „To jest bowiem kielich Krwi mojej”. W modlitwie eucharystycznej, w której wszyscy zostaliśmy zaproszeni do wzięcia udziału, przeżywamy akcję samego Boga. On inauguruje nowe stworzenie, czyniąc się dostępnym dla każdego z nas i poprzez dary ofiarne pozwala nam komunikować się z nim w sposób osobisty ${ }^{97}$.

Podczas trwania modlitwy eucharystycznej nie wystarczy czytanie „tekstu” przyporządkowanego kapłanowi, czy też powiększanie ilości aklamacji, które należałyby do zgromadzenia wiernych. Nie wzbudzi to automatycznie ani u jednej, ani u drugiej strony realnego uczestnictwa w misterium. Trzeba nam spróbować wejść w to misterium, proponowane nam do odkrycia, $\mathrm{z}$ każdej strony i to przez całe zgromadzenie liturgiczne. Celebrans główny sam musi być przeświadczony o bogactwie modlitwy eucharystycznej i jej różnorodnych formach, wtedy tylko będzie mógł zaproponować modlitwę najbardziej odpowiadającą sytuacji zgromadzenia liturgicznego. Inaczej, trzeba nam przyjrzeć się z bliska formie

${ }^{95} \mathrm{~J}$. Gelineau, La prière eucharistique comme action de l'assemblée. Trente-cinq ans de recherches et d'expériences sur la célébration de la prière eucharistique dans la messe romaine après Vatican II, „Liturgie" 122 (2003), s. 143.

${ }^{96}$ B. D. Marliangeas, Les acclamations dans la prière eucharistique, „Notes de Pastorale Liturgique” 99 (1972), s. 32.

${ }^{97}$ J. Ratzinger, L'Esprit de la liturgie, trad. par G. Català, Genève 2002, s. 137-139; G. de Servigny, La Théologie de l'Eucharistie dans le concile Vatican II, Paris 2000, s. 72-77. 
ekspresywnej, w jakiej tekst modlitwy eucharystycznej jest proponowany wspólnocie celebrującej. Zbyt często tekst jest mamrotany, czy też rozwlekany, nawet więc gdy jest znany, pozostaje niedostępny dla wiernych. Zwrócenie szczególnej uwagi na dykcję może nam dopomóc w respektowaniu dynamiki tekstu. W rzeczywistości trzeba nam prześledzić strukturę tekstu każdej modlitwy eucharystycznej, bez uwypuklania poszczególnych części, gdyż one naturalnie następują po sobie. Bez zachowania tych podstawowych zasad nie można mówić o uczestnictwie aktywnym zgromadzenia liturgicznego ${ }^{98}$.

\subsection{Aklamacje dziękczynienia}

Pierwszą postawą chrześcijanina przed Bogiem jest dziękczynienie. Taki jest również cel pastoralny modlitwy eucharystycznej, która dałaby możliwość wydobycia z serc wiernych zgromadzonych w Kościele „wielkich postaw” składających się na Eucharystię, która sama jest dziękczynieniem par excellence. List okólny Kongregacji Kultu Bożego Eucharistiae participationem, przed ukazaniem się MEP, nalegał na potrzebę zaproponowania w liturgii większego wyboru tekstów, które pozwoliłyby na prawdziwą adaptację do szczególnych okazji. W tym samym czasie dokument rzymski zaakcentował potrzebę wykorzystania wszelkich możliwości modyfikacji przewidzianych w nowej liturgii mszalnej9.

Wspominaliśmy już o wprowadzeniu aklamacji anamnetycznej w tekstach modlitw eucharystycznych, które ukazały się po reformie Pawła VI. W pracach przygotowujących reformę były również inne propozycje aklamacji podczas modlitwy eucharystycznej, ale tylko aklamacja anamnetyczna znalazła miejsce w Mszale rzymskim, który był wynikiem wspomnianej reformy. Pozwala ona, wraz z dialogiem rozpoczynającym prefację, Sanctus i Amen kończącym modlitwę, na animację wspólnoty wiernych podczas modlitwy eucharystycznej. $\mathrm{Z}$ reguły te części są śpiewane, ale zdarza się, że są recytowane oraz bardziej lub mniej zintegrowane $\mathrm{z}$ tekstem wypowiadanym przez kapłana. Pasterze zatroskani o aktywne uczestnictwo wspólnoty zauważą szybko potrzebę wprowadzenia innych aklamacji, aby zatrzymać uwagę wiernych. W następstwie możemy zaobserwować rozwój innego typu aklamacji, poza momentami przewidzianymi

${ }_{98}$ B. Baroffio, La preghiera eucaristica luogo reale di partecipazione attiva dell'assemblea, art. cyt., s. 641-642; G. Genero, La preghiera eucaristica nel suo momento celebrativo, w: R. Falsini, La preghiera eucaristica, modello della preghiera cristiana, Milano 1995, s. 155-157.

${ }^{99}$ Kongregacja Kultu Bożego, List okólny Eucharistiae participationem, 7-12; Ph. Béguerie, D. Dye, P. M. Gy, J. Y. Hameline, D. Rimaud, La prière eucharistique. Initiation à la prière chrétienne, LMD 125 (1976), s. 48. 
w oficjalnym rycie Eucharystii. Wydaje się, że odpowiedzialni za Kongregacje rzymskie również odczuwają taką potrzebę, gdyż dopuścili pewnego rodzaju rozszerzenia możliwości wykorzystania innych aklamacji $\mathrm{w}$ modlitwach eucharystycznych $\mathrm{z}$ udziałem dzieci oraz w rycie zairskim.

Możemy zaobserwować rozwój następujących aklamacji w ramach pewnych liturgii bardziej uroczystych: aklamacje uwielbienia w ramach prefacji, specjalne błagania w prośbach, adoracja towarzysząca słowom konsekracji oraz specjalne prośby przy dwóch epiklezach ${ }^{100}$.

Ograniczymy się do przedstawienia aklamacji, które były proponowane przez Prof esor Irmgard Pahl w próbie przetłumaczenia I MEP na język niemiecki. Inspirowała się ona niemiecką wersją drugiej modlitwy eucharystycznej w Mszy $\mathrm{z}$ udziałem dzieci.

W prefacji po liniach: 8, 14 i 20 [tekstu oryginalnego] proponuje śpiew wersetów uwielbienia i dziękczynienia:

K: „Ty zapraszasz grzesznego człowieka, aby powierzył się twojej dobroci".

Tobie niech będzie uwielbienie.

$\mathrm{W}$ : Tobie niech będą dzięki i cześć.

K:/W: Tobie niech będzie chwała, dzięki i cześć.

K: „Nowe Przymierze tak mocne, że nic nie może go złamać”.

Boże, Ty jesteś dobry.

W: Uwielbiamy Cię, dziękujemy Ci.

K:/W: Uwielbiamy Cię, wysławiamy Cię (czy: dziękujemy Ci).

K: „Być dyspozycyjnym dla każdego człowieka otwierając się bardziej na Ducha Świętego".

Pan nas uwolnił.

W: Na wieki trwa Jego Przymierze.

W prośbach, po anamnezie, ale przed doksologią, według naszej autorki jedno błaganie mogłoby być dorzucone po liniach 85 b i 94 :

K:/W: Ześlij Ducha Swego i odnów oblicze ziemi.

Na zakończenie proponuje wzmocnić Amen śpiewane po doksologii modlitwy eucharystycznej przez powtarzanietej kończącej aklamacji. Nawet jeśli I. Pahl obawia się, ażeby I MEP nie stała się zbyt długa i proponuje skrócenie jej

${ }^{100}$ B. D. Marliangeas, Les acclamations dans la prière eucharistique, art. cyt., s. 35-37; dla innych form aklamacji w trakcie modlitwy eucharystycznej: pieśń stroficzna, kontynuowany hymn, zob. J. Gelineau, Les chants de la Messe dans leur enracinement rituel, Paris 2001, s. 86-93 i 99-101; tegoż, New Models for the Eucharistic Prayer as Praise of All the Assembly, „Studia Liturgica” 27 (1997), s. 84-87. 
lub użycie fakultatywne niektórych wersetów, nie waha się natomiast dorzucenia aklamacji przedstawionych powyżej. Uważa bowiem, że aklamacje mogą pozytywnie podziałać na zgromadzenie liturgiczne i utrzymać jego uwagę ${ }^{101}$.

Aklamacje zaproponowane $\mathrm{w}$ trakcie modlitwy eucharystycznej powinny dobrze zintegrować się $\mathrm{z}$ tekstem czy to mówionym, czy też śpiewanym. Jest rolą celebransa głównego, aby je połączyć w jedną całość nieprzerwaną, rozwijającą się, zorientowaną i rytmiczną, jednym słowem w oratio modlitwy eucharystycznej. Ksiądz Joseph Gelineau proponuje pewną technikę specjalną: ekphonèse, aby lepiej połączyć aklamacje wspólnoty i tekstu wypowiadanego przez kapłana. Polega ona na podnoszeniu głosu, aby „wyśpiewać” zakończenie tekstu modlitwy lub części modlitwy, mówionej lub śpiewanej, w ten sposób, by chór lub wspólnota wiernych bezpośrednio mogli podjąć śpiew w swojej odpowiedzi ${ }^{102}$.

\subsection{Publiczna komunikacja słowna}

Liturgia przedsoborowa oparta była przede wszystkim na tekście pisanym. Wszystko było opisane w mszale i było recytowane w języku martwym. Od tego czasu dokonała się wielka przemiana, w wielkiej mierze dzięki nowym środkom komunikacji. Hegemonia tekstu pisanego załamała się, a w jej miejsce zaczęło dominować słowo. Jeśli nawet media współczesne posługują się sposobami komunikacji, nie do końca stosownymi we wspólncie liturgicznej, użyczają wspólnocie celebrującej doświadczenia, które może dopomóc odkryć techniki własne do komunikacji w zgromadzeniu liturgicznym ${ }^{103}$.

Przedsoborowe zgromadzenie liturgiczne $\mathrm{z}$ reguły było statyczne i oczekiwało prawie wyłącznie na moment konsekracji, gdzie przez akt adoracji oddawało chwałę Bogu. Po okresie pasywnego asystowania akcji liturgicznej, gdzie kapłan modlił się przed ludem, komunikując się z nim zaledwie poprzez kilka gestów i kilka słów, współczesne zgromadzenie liturgiczne staje się samo celebransem akcji liturgicznej pod przewodnictwem kapłana. Ten ostatni, aby popierać udział aktywny wiernych w liturgii powinien wyraźnie i głośno wypowiadać tekst, który mu przypada. Ton jego głosu „winien odpowiadać

101 I. Pahl, Das erste Versöhnungshochgebet, w: Gratias agamus, dz. cyt., s. 360-361; por. R. Ponczek, Wielka modlitwa Kościoła o pojednaniu. Przesłanie teologiczno-liturgiczne w Modlitwach eucharystycznych o tajemnicy pojednania, Toruń 2000, s. 32-33.

${ }^{102}$ J. Gelineau, Les chants de la prière eucharistique, w: Dans vos Assemblées, dz. cyt., s. 477-478; tegoż, La prière eucharistique comme action de l'assemblée, art. cyt., s. 156.

${ }_{103}$ Tegoż, Une technique à retrouver: le bon usage d'un modèle dans les prières liturgiques, LMD 114 (1973), s. 86-88; L. Leijssen, La communauté eucharistique: communauté de personnes en action, dz. cyt., s. $130-135$. 
rodzajowi tekstu, zależnie od tego, czy jest to czytanie, oracja, zachęta, aklamacja, śpiew; winien też być dostosowany do formy celebracji i uroczystego charakteru zgromadzenia" (OWMR 38). Wydaje się, iż ten element nie do końca został jeszcze opanowany przez tych, którzy przewodniczą zgromadzeniom liturgicznym. Na nieszczęście, całe zgromadzenie liturgiczne może stać się "ofiarą" złej interpretacji tekstu, gdy na przykład ton recytatywu nie służy dobremu jego zrozumieniu. W konsekwencji, element ten nie będzie służył ani dobrej modlitwie, ani skupieniu, oczekiwanemu przez zgromadzonych ${ }^{104}$.

Poza dialogiem rozpoczynającym prefację cała modlitwa eucharystyczna adresowana jest do Boga Ojca. Celebrans główny powinien zdawać sobie z tego sprawę wypowiadając swój tekst i nadając odpowiednie zabarwienie modlitwie. Tekst ten nie jest skierowany bezpośrednio do wspólnoty zgromadzonej, jak to miało miejsce w homilii, w której głoszący wzywał do nawrócenia, ukazując Chrystusa jako dobry przykład. Nie jest to tym bardziej moment, w którym powinien on ukazywać własną pobożność, jak podczas kierownictwa duchowego, czy adoracji eucharystycznej. Kapłan wypowiada modlitwę Kościoła, jest bowiem w tym momencie w służbie całej wspólnoty w imieniu której zanosi modlitwy przed tron Boży. Jeżeli mówi zbyt głośno, ryzykuje być zbyt agresywnym wobec wspólnoty, która potrzebuje spokoju, by wejść w modlitwę przez niego wypowiadaną. Jeśli mówi zbyt nisko, tym bardziej nie przyczynia się do dobrego przyjęcia modlitwy przez wiernych. Gdy mówi zbyt szybko, zapewne część zgromadzonych nie potrafi za nim nadążyć, zbyt wolno, będzie wyprzedzony przez wspólnotę, która przecież prawie zawsze zna tekst używanej modlitwy ${ }^{105}$.

Tekst modlitwy eucharystycznej wraz ze wszystkimi aklamacjami powinien być stały i znany wspólnocie liturgicznej. Niemniej jednak, nie jest to wymóg absolutny, aby osiągnąć udział aktywny wiernych w Eucharystii. W stałym schemacie potrzeba też części zmiennych; zarówno w tekstach, jak i w melodiach one mogą bowiem rozbudzić uwagę obecnych ${ }^{106}$.

Można by zaproponować, wraz z Didier Rimaud, jako próbę rozwiązania problemu związanego z komunikatywnością języka naszych celebracji „recytatyw muzyczny”. Może być on zaproponowany niektórym częściom modlitwy eucharystycznej, które mogą być śpiewane. Recytatyw ukazuje przynajmniej jakiś kierunek, gdzie należy szukać rozwiązania trudności związanych z komunikatywnością.

${ }^{104}$ T. Matus, Preghiera nello Spirito e dimensioni non-verbali della Liturgia, „Vita Monastica” 43 (1989), nr 176, s. 68-69.

${ }^{105}$ D. Rimaud, Célébrer la prière eucharistique, „Célébrer” 231 (1993), s. 15-16; G. Genero, La preghiera eucaristica nel suo momento celebrativo, art. cyt., s. 152-156.

${ }^{106} \mathrm{~J}$. Gelineau, La prière eucharistique comme action de l'assemblée, art. cyt., s. 156-157. 
Może to być spokojny recytatyw bez jakichś wielkich emocji, aby mógł być kontrolowany w swojej wymowie, barwie i sile głosu ${ }^{107}$.

\subsection{Postawy i gesty podczas modlitwy eucharystycznej}

Mówiliśmy już o znaczeniu niektórych gestów i ich sensie mistagogicznym. W liście apostolskim Mane Nobiscum Domine Ojciec święty Jan Paweł II ogłaszając rok Eucharystii napisał: „Cała Eucharystia sprawowana jest w dynamicznym kontekście znaków, które niosą w sobie bogate, jasne przesłanie. To właśnie przez znaki tajemnica niejako odsłania się przed oczami wierzącego"108. Ilość gestów w czasie modlitwy eucharystycznej po Soborze Watykańskim II zmniejszyła się. Rubryki dotyczące gestów celebransa w nowym Ordo Missae stały się rzadsze, ale wszystko zorientowane zostało w kierunku dobrego funkcjonowania modlitwy, tzn. w kierunku jej należytego odbioru przez zgromadzoną wspólnotę. Należy dorzucić jeszcze fakt, iż modlitwa eucharystyczna zatrzymała postawy i gesty typowe dla najdawniejszej tradycji modlitwy chrześcijańskiej: rozkładanie i nakładanie rąk, skłony i przyklęknięcia, czy też podniesienie i okadzanie darów eucharystycznych.

Celebrans główny, czy ewentualni koncelebransi oraz ci, którzy im usługują, powinni więc zachowywać się naturalnie $\mathrm{z}$ właściwą prostotą. Wyraża się to poprzez pewnego rodzaju ekonomię ruchów, poprzez język korpusu ciała i oczu, w gestach wykonywanych rękami, ramionami i całym ciałem. Jest także bardzo ważne, aby postawa sprawującego liturgię asystowała prawie naturalnie tekstowi modlitwy eucharystycznej. Nie może on pozostać „przywiązany do ołtarza jak tyczka” z oczyma przykutymi do mszału. Jego znaki powinny być komunikatywne, a oczy stać się nosicielami tejże wymiany informacji. Jednocześnie, śledzenie i zrozumienie modlitwy eucharystycznej stanie się o wiele łatwiejsze. Wszystko to pozwoli zgromadzeniu liturgicznemu naturalniej przylgnąć do modlitwy recytowanej, czy też śpiewanej przez kapłana ${ }^{109}$.

Nie wolno pozostawiać celebransa głównego samego przy ołtarzu zwróconego do wiernych, którzy zwykle zajmują miejsca daleko od ołtarza. Powinien być on w bliskości służby liturgicznej, czy też wiernych, ponieważ najpierw działa on in persona Ecclesiae. Nawet jeśli ołtarz soborowy jest ustawiony w centrum świątyni, aby sprzyjać uczestnictwu bardziej czynnemu w liturgii, nie trzeba bać się zbliżyć do ołtarza. Należy za wszelką cenę unikać

${ }^{107}$ D. Rimaud, Célébrer la prière eucharistique, art. cyt., s. 16.

${ }^{108}$ Jan Paweł II, List Apostolski Mane Nobiscum Domine, 14.

${ }^{109} \mathrm{G}$. Genero, La preghiera eucaristica nel suo momento celebrativo, art. cyt., s. 157. 
pustki, wytwarzającej się pomiędzy kapłanem i ołtarzem, a wiernymi i resztą nawy kościoła. Tym bardziej, że w większości naszych kościołów ołtarz główny znajduje się $\mathrm{w}$ prezbiterium, które naturalnie jest oddalone od wiernych. Ponadto, uczestnictwo wiernego ukrytego za filarem, czy też głęboko pod chórem, nie wspominając tych, którzy stoją w przedsionku lub na zewnątrz kościoła, skąd nic nie mogą zobaczyć ani za dużo usłyszeć, nie będzie nigdy ani aktywne ani owocne ${ }^{110}$.

Powinniśmy zwrócić baczniejszą uwagę na gesty rąk celebransa podczas modlitwy eucharystycznej. Gdy nie trzymają one kielicha lub chleba eucharystycznego, mogą być:

- złączone, w pewnych momentach ciszy czy modlitwy wypowiadanej przez pochylonego kapłana;

- nałożone, ponad chlebem i winem w momencie epiklezy konsekracyjnej;

- wzniesione, podczas dialogu prefacji: „W górę serca”;

- rozpostarte, podczas całej modlitwy eucharystycznej wypowiadanej głośno przez kapłana w imieniu zgromadzenia liturgicznego.

Pozycja rąk i ciała celebransa ma pomóc wspólnocie wejść w obecność Chrystusa, który sam jest głównym celebransem, w pełnym tego słowa znaczeniu. Oczywiście, to wszystko wymaga również uwagi zgromadzenia liturgicznego. Gdy kapłan celebruje nerwowo lub zbyt spokojnie, sztywno lub w sposób zmanierowany, albo bez żadnej synchronizacji ze słowami wypowiadanymi, celebracja traci automatycznie aspekt prawdziwości i tego, czym tak naprawdę jest. Ponadto, gdy wierni śledzą oczyma tylko własny tekst w „Oremus”, czy też innych mszalikach, czy gorzej, nie potrafiąc nawet odnaleźć tekstu modlitwy eucharystycznej, ponieważ kapłan tym razem wybrał modlitwę inną niż ta, do której byli zwykle przyzwyczajeni, nie można za bardzo w takim wypadku mówić o uczestnictwie aktywnym wspólnoty w modlitwie eucharystycznej Kościoła ${ }^{11}$.

W rzeczywistości, jest bardzo trudno w naszych wspólnotach przyjąć i przeżywać modlitwy eucharystyczne drugą i trzecią, które już istnieją i są często używane. Ponieważ modlitwa eucharystyczna nie jest jeszcze do końca rozumiana jako jedność dynamiczna, pozwalająca nam wejść w misterium paschalne Chrystusa, ale bardziej jako zbiór statyczny prostych modlitw mniej lub bardziej zmiennych. Czy można zatem wymagać, by zgromadzona wspólnota weszła w głębię Eucharystii jako ofiary pojednania, gdy większość

${ }^{110} \mathrm{~J}$. Gelineau, La prière eucharistique comme action de lassemblée, art. cyt., s. 159.

${ }^{111}$ D. Rimaud, Célébrer la prière eucharistique, art. cyt., s. 15. 
wiernych nie zdaje nawet sobie sprawy z istnienia MEP? Nawet jeśli wiedzą o ich istnieniu, nie mają prawie żadnych szans, by je usłyszeć w naszych kościołach. Jak wspólnota liturgiczna może pogłębić swoją wiarę i zrozumieć zdobycze teologiczne wszystkich aspektów misterium zbawienia, zgodnie ze starożytną maksymą głoszącą, iż "prawo modlitwy” determinuje „prawo wiary”, bez możliwości celebrowania Eucharystii $\mathrm{z}$ jedną $\mathrm{z}$ modlitwy eucharystycznych o tajemnicy pojednania?

Jeśli artykuł ten pomógłby indywidualnemu wiernemu, czy też zgromadzeniu liturgicznemu lepiej zrozumieć i pogłębić charakter pojednania w sprawowanych celebracjach eucharystycznych, autor cieszył się będzie spełnieniem założonej misji. 